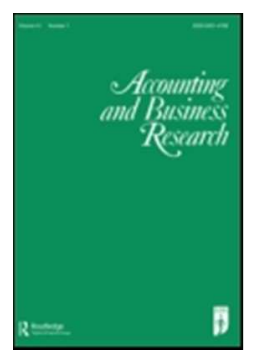

\title{
Capital reduction case law decisions and the development of the capital maintenance doctrine in late nineteenth century England
}

\begin{tabular}{|r|l|}
\hline Journal: & Accounting and Business Research \\
\hline Manuscript ID & ABR-2015-0205.R2 \\
\hline Manuscript Type: & Original Article \\
\hline Keywords - Group 1: & Accounting history \\
\hline Keywords - Group 2: & Archival (i.e. empirical study using publicly available data) \\
\hline ADD your Keywords: & $\begin{array}{l}\text { Capital reduction schemes, Shareholder class rights, Capital maintenance, } \\
\text { Nineteenth century accounting }\end{array}$ \\
\hline \multicolumn{2}{|l}{} \\
\hline
\end{tabular}

SCHOLARONE ${ }^{m}$

Manuscripts 


\title{
Capital reduction case law decisions and the development of the capital maintenance doctrine in late nineteenth century England
}

\begin{abstract}
(197 words)
Incorporation with limited liability enabled companies to 'lock-in' their financial capital' and then invest in the long-term, highly specific investments on which the modern industrial economy would be based. The level of benefit varied from country to country, according to the way that the concept of capital lock-in, or maintenance, was defined in the legal systems concerned.
\end{abstract}

In the UK, the concept was not well defined in early company legislation and challenges were raised through the courts during the late nineteenth century. Some of these, the 'dividend cases', have been quite widely considered in the literature but direct reductions of share capital, or capital reduction schemes, have received far less attention, even though they raised fundamental issues concerning long-term dividend positions, the accounting treatment of accumulated losses, depreciation and asset values and had important effects on the development of the capital maintenance doctrine and on shareholder class rights.

The purpose of this paper is to question whether this literature adequately captures judicial influences on the development of the capital maintenance doctrine in England during the latter part of the nineteenth century, given the limited attention that has been paid to date to the leading capital reduction cases.

\section{Keywords}

Capital reduction schemes

Shareholder class rights

Capital maintenance

Nineteenth century accounting 


\section{Capital reduction case law decisions and the development of the capital maintenance doctrine in late nineteenth century England}

\section{Introduction}

Incorporation with limited liability is a business device that enabled nineteenth century firms to amass large amounts of capital. Blair has recently argued that this was one of their main advantages. Companies had the 'ability to commit capital, once amassed, for extended periods of time' and the 'unique manner in which incorporation permitted organizers to lock-in financial capital' made them highly popular in the nineteenth century (Blair 2003a, p. 387). ${ }^{1}$

The arrangement was also beneficial to the economy; once locked-in, capital could more easily be spent on the 'long-term, highly specific investments' on which the modern industrial economy would be based (Blair 2003a, p. 390), although the level of benefit was bound to vary from country to country, according to the way that the concept of capital lock-in, or maintenance, was defined in the legal systems concerned. In the UK, companies could be formed with limited liability by simple registration from 1855 and by the end of the nineteenth century, as accounting practices became more established, statutes and court cases had addressed the question of what the concept of capital maintenance really meant.

Case law was very important to this process, given the reluctance of the legislature to fully define the workings of incorporation -- 'distributable profits', for example, were not defined by legislation until 1980 -- and Ardern and Aiken, in a recent 'accounting history of capital maintenance', saw 'disputes concerned with measurement issues, while relatively few' as 'centred on the recurring debate over the amount of profits available for the purposes of dividend distribution' (Ardern and Aiken 2005, p. 24). French concluded that 'many of the points of potential weakness of the capital maintenance doctrine were explored in litigation' in the period 1862 to 1889 (French 1977, p. 309) while Yamey also argued that 1889 (the date of the decision in Lee $v$ Neuchatel Asphalte Company) was of pivotal importance to the development of the capital maintenance concept in England (Yamey 1941, pp. 274-78).

A substantial literature has considered a wide set of late nineteenth century court cases, 'the dividend cases', and arrived at a number of conclusions. The purpose of this paper is to

1 Ribstein has argued that capital lock-ins were also available through the partnership form and that the lock-in was 'backed by politically influential corporate managers because of its role in underpinning managers power ... over the corporate cash'; 2005, pp. 524, 538. 
question whether this literature adequately captures judicial influences on the development of the capital maintenance doctrine in England during the latter part of the nineteenth century, given the limited attention that has been paid to date to the leading capital reduction cases. The paper is divided into five sections. The next discusses the capital maintenance concept and identifies the various mechanisms that affect it. A third section examines the early capital reduction cases and the financial and industrial context within which they were presented to the courts in the latter part of the nineteenth century. The most difficult issue that these cases had to consider was the treatment of the existing assets of firms in declining trades with complex shareholder class rights. The leading cases in this difficult area arose out of two major capital reduction schemes at one of the largest steel companies in the world, Barrow Haematite Steel Company Ltd (BHS) and, in the fourth section of this paper, the judicial decisions on these cases are related to an analysis of its financial situation, accounting practices and approach to capital maintenance. ${ }^{2}$ This provides the basis for discussion and conclusions in the final section of the paper.

\section{The capital maintenance concept and the mechanisms that affect it}

The concept of capital lock-in, or maintenance, is central to class rights under company law and to economic and accounting formulations of profit. As Ferran explains, 'at the heart of English company law is the recognition that there is a price to be paid for limited liability in the form of restrictions on the use of the company's capital' (1999, p. 355). Here 'capital' clearly means ownership monies put into the business. The word 'capital' in this paper also generally refers to ownership inputs, except where indicated otherwise. Owners, as shareholders in a limited company, are able to limit their exposure to the claims for repayment of the creditors of that business by meeting legal requirements to publish financial information about the business and by accepting that the circumstances under which ownership capital can be returned will be circumscribed.

Capital maintenance is also central to the concept of economic income which underpins accounting measurements of profit. Thus, to Hicks, income was the maximum amount that could be consumed during a week, still leaving the consumer 'as well off at the end of the week as he was at the beginning' (1948 p. 172), an approach which can be readily reformulated to fit

2 See re Barrow Haematite Steel Company (1888) L.R. 39 Ch. D. 582; re Barrow Haematite Steel Company (1900) 2 Ch. 846; re Barrow Haematite Steel Company (1901) 2 Ch. 746; Bond v Barrow Haematite Steel Company (1902) 1 Ch. 353. The company also obtained an Act of Parliament in 1902 that resolved some of the issues concerned; Barrow Haematite Steel Co. Ltd Act 1902. 
business units. ${ }^{3}$ Under such an approach, the capital (of the owners) has been maintained when the amount of net assets at the end of a period is at least equal to the amount at the beginning of the period, excluding any inflows from or outflows to the owners. This basic identity is, however, more problematic than it sounds as there are many different ways to calculate the 'amount' or value of the net assets at the successive points in time.

Although the principle of capital maintenance is simple, the inherent uncertainties of business trading operations (and of the asset valuation process) mean that the concept cannot be (continually) applied in its literal form. Instead of attempts at the "preservation intact of the value of the shareholders' contribution of assets to a company - i.e. a rule requiring the maintenance of some net asset value', what emerged instead was a requirement 'merely that capital must not be returned to shareholders' before the business was liquidated. ${ }^{4}$ A priori, this could occur in only two ways; through the redemption or purchase of a company's own shares (with or without financial assistance for the purchase) or through the making of dividend payments (or other distributions) to shareholders beyond the identified amounts of the asset surpluses. In recent years the rules that govern these areas have been more closely defined by legislation but, during the late nineteenth century, a formative period for both company law and accounting practice, the definition of these matters by legislation was quite limited and often had to be extended by decisions of the courts.

The first of these areas, the redemption or purchase of a company's own shares, was not in fact a very important issue at the time, given the clear conclusion of the House of Lords in Trevor $v$ Whitworth in 1887 that the practice was unlawful, even to buy out shareholders whose continued presence in the company was undesirable. Lord Macnaughton doubted whether it was possible to 'suggest anything more dangerous to the welfare of companies and to the security of their creditors than such a doctrine'. ${ }^{5}$

Without share redemptions, the only way that capital can be returned to the shareholders is by way of a dividend payment in situations where the net value of assets had not been maintained. This could only occur with the permission of the courts, but could arise through two distinct mechanisms; firstly if it was agreed that certain losses did not need to be

\footnotetext{
3 See, for example, the Report of the Sandilands Committee on Inflation Accounting (1975). It has been argued that a distinctive quality of capitalism is its reasoning in terms of return on capital (profit divided by capital); see Chiapello 2007; Bryer 2000; also Toms 2010.

4 This was clearly expressed in court cases in 1882 and 1887, although 'for practical purposes, the common law principle has been surpassed by the statutory rules introduced in 1980'; Armour 2000, p. 365. See also the Companies Acts of 1947-48, 1985 (Parts V and VIII) and 2006 (Parts 17, 18 and 23). 5 See (1887), 12 App Cas 409, HL. The issuing of redeemable preference shares became possible under the Companies Acts 1947-48, an arrangement extended to ordinary shares by the Companies Act 1981 .
} 
recognised or, having been recognised, could still be ignored for the purpose of calculating the dividend fund (i.e. the maximum possible dividend) or, secondly, if it was agreed that certain losses could be deducted from share capital (or perhaps held as a negative reserve on the balance sheet) rather than charged to profit and loss. The first mechanism led to cases (the 'dividend cases'), that sought the court's view on the legitimacy of immediate dividend payments. The second asked the courts to accept specified reductions in net asset values as permanent and to reduce the share capital part of the ownership claim on the business, rather than charge the losses to profit and loss. This would mean that dividends might the sooner be paid out of any future surpluses, without the encumbrance of accumulated losses on the net assets concerned. Early case law indicated that the resources invested in corporations "no longer belonged to the shareholders but, rather, remained the property of the corporation unless and until paid out in the form of dividends'. ${ }^{6}$

It will be argued in this paper that, even if the mechanisms were distinct, the main issues that the courts considered in the capital reduction cases were similar to and thus overlapped those raised in the dividend cases. Arguably, however, the effects of the capital reduction cases on the capital maintenance doctrine were the greater, given the direct and wide-ranging questions they raised on asset valuation issues.

The idea of capital maintenance had been inherited from the eighteenth century charter corporations' and reinforced by section 121 of the Companies Clauses Consolidation Act, 1845. Effectively, it 'opposed the notion that limited companies may cancel paid up share capital which was no longer represented by assets', although the Companies Act, 1867 did 'introduce weaknesses' into the doctrine by allowing (under sections 9-14) companies to cancel or reduce capital, surplus to their requirements, if the consent of the court was obtained and after any creditor objections had been heard (French 1977, pp. 306-07, 311-12). ${ }^{7}$

It was quite common for the statutes and charters of early companies to state that their dividends could not be paid out of capital or that they were only payable out of profits and it was then for the directors to decide whether a dividend could be paid, although challenges

\footnotetext{
6 Blair 2003b, p. 18. See Hope v International Financial Society Ltd, (1877) 46 L. J. Ch. 200 regarding the general principle of capital reductions under court supervision. The 1985 Companies Act, s. 142 did later require that a shareholders meeting be called when a company's net assets fell below one half of its called-up share capital.

7 Since October 2008, under the Companies Act 2006, new procedures are available in situations where capital may have been lost that enable private companies to put forward solvency statements signed by directors instead of seeking the approval of the courts. As Edwards points out, however, solvency tests may work satisfactorily in the short-term but fail to maintain the capital of the business in the long-term; Edwards 1989, p. 182. See also Mason 1932, pp. 64-65.
} 
could be mounted through the courts (see McCartney and Arnold 2012). At first the two phrases 'could not be paid out of capital' and 'only payable out of profits' may have been viewed as synonyms, although the differences between them became important later in the latter part of the nineteenth century (see below).

The courts generally expected the directors to 'decide whether a company could afford to pay a dividend' but they could intervene as, for example, where the profits were inadequate (e.g. when a debt was known to be bad). Flitcroft's case in 1882 established 'beyond doubt the directors' obligation to ... maintain capital intact', although it did not establish any general rule for asset valuation (Edwards 1989, pp. 177-84). The cases cover a wide range of expenses and circumstances 'concerned with establishing whether profit had been properly measured, principally for the purpose of discovering whether a legitimate dividend had been paid'. 8

The most important case was probably Lee $v$ Neuchatel Asphalte Company (1889), in which it was decided that depreciation (at least in the case of a quarry working) did not have to be charged when calculating distributable profit and that the quarry might be valued at original cost for the purpose of deciding whether capital had been maintained intact'. Yamey felt that 'a single unifying idea' (the disapproval of the Legislature of 'any dividend payment which would have left the company with a sum of assets less, in value, than its nominal paid-up capital') had run through the decisions in previous cases and that the Lee decision 'destroyed the existing capital maintenance' theory of the dividend fund in one fell stroke' by approving the 'practice of ignoring declines in the value of a company's property' (Yamey 1941, pp. 274-78). ${ }^{9}$ Edwards, on the other hand, thought the cases, including Lee, helped to 'clarify profit measurement procedures at a time when there were no statutory regulations or generally accepted accounting procedures in the modern sense of the term' (Edwards 1989, p. 177).

The case was also important as Lindley, L J indicated that "profit measurement was a matter for businessmen and not a proper subject for an Act of Parliament'; identified his concerns that a strict interpretation of the capital maintenance doctrine might mean that funds would be 'arbitrarily locked into business entities' and thereby 'prohibit honest business and paralyse

\footnotetext{
8 Expenses generally caused greater problems although profit measurement issues could also arise over receipts. See Yamey 1941; French 1977; Reid 1986, 1987a, 1987b, 1988; Morris 1986; Edwards 1989, pp. 177-84.

9 See also Verner (1894) in which Lindley, L J, made clear the new rule; assets were to be divided into two classes, fixed and circulating, and only declines in the value of the latter needed to be allowed for in calculating the size of the dividend fund. The fact that depreciation on fixed assets could be ignored was confirmed in re Kingston Cotton Mills Co. No. 2 (1896) 1 Ch 331. Later, Ammonia Soda Company $v$ Chamberlain (1918) 1 Ch. 266 took decisions on unrealized increases in the value of property; Yamey 1941, pp. 280-84.
} 
the trade of the country'; and that capital should be understood as the assets rather than the ownership inputs and then restricted to its circulating and not fixed elements. ${ }^{10}$

\section{The main capital reduction cases and their financial and industrial context}

The last quarter of the nineteenth century was a period in which trading conditions were quite difficult in some industries, particularly in iron and steel, the 'first manufacturing industry to require capital expenditure on a sufficient scale to stimulate the widespread adoption of joint stock company status' (Edwards 1980, p. 243). There were considerable technological changes in iron and steel in the second half of the nineteenth century that encouraged investment but also brought long periods of 'uncertainty, pessimism and ... stagnation'; in 1875, Britain produced almost 40 percent of the world's steel but by 1896 its output had fallen to 22.5 percent. ${ }^{11}$ This meant that, in an important industry that had invested heavily in long-term, highly specific assets, the directors of many companies had good reason to believe that a good deal of the shareholders' money was tied up in assets with poor commercial prospects.

During the same period of time, the capital structure of companies in a wide range of industries had changed considerably; although 'few companies during the 1860s and early 1870s made use of loan capital', by 1895 , preference shares represented $22.5 \%$ and debentures $40.6 \%$ of aggregate paid-up capital. ${ }^{12}$ Preference shares (which were permanent not redeemable until 1948) were likely to have preferential rights concerning dividends (and perhaps cumulative rights thereto) and possibly as far as repayment of capital was concerned. Debentures would carry a defined right to interest payments, whether or not profits had been earned (as would loans from banks and other parties providing temporary finance). These developments meant that capital maintenance would no longer have to consider merely the competing rights of ordinary shareholders and trade creditors but would in many cases have to also address more complex sets of financial entitlements and claims on the business.

By 1876, the value of the assets of the Ebbw Vale Steel, Iron and Coal Company Ltd, formed eight years earlier, had been eroded by a 'great fall ... in the value of iron and coal' and the board sought to write down their ordinary shares (the only class of share capital) by about a third. The court ruled that (with regret) they were not able to do this, as the proposal was 'not an actual reduction, because the capital has (already) been lost. It is merely acknowledging

10 Ardern and Aiken 2005, p. 48; French, 1977, p. 315; Edwards 1989, p. 180.

11 The successive Gilchrist-Thomas, acid steel, Siemens and basic steel processes; see McCloskey 1970, p. 448; Floud 1994, pp. 3-4, 15; Birch 1967, pp. 353-86; Roepke 1956, pp. 56-61; Carr and Taplin 1962, pp. 94-97, 123-28; Andrews and Brunner 1951; Abe 1996.

12 See Rutterford 2009; Cottrell 1980, p. 86. By 1915, these proportions would be $30.1 \%$ and $40.7 \%$ respectively: Cottrell 1980, p. 164; see also Jefferys 1946. 
that to be lost which is lost'. Instead, Jessel, M. R. said, the Companies Act 1867 allowed only actual reductions of capital, such as a cancellation of the obligation of the shareholders for further calls on their shares (e.g. in a situation in which the company no longer needed such a large nominal share capital; re Ebbw Vale Steel, Iron, and Coal Company, 1877).

The legal position was changed by a small Companies Act passed later that same year. Capital reductions were now possible under two circumstances; where a reduction of capital could prejudice the creditors (e.g. by lessening the liability of shareholders for unpaid capital, in which case the creditors would have a right of objection) and those where it would not, including instances where 'the assets representing the paid up capital had been lost' (French 1977, p. 312). The new rules thus provided an amended basis for determining a balance of rights of shareholders and creditors, although they did not fully address situations involving different classes of shareholders or where the loss of asset value might be less obvious.

The first signs of the difficulties of accommodating preference shares, in the late nineteenth century, to a capital maintenance doctrine shaped by the more fundamental differences between creditors and ordinary shareholders emerged in 1886, in a case in which the loss of asset value could not have been more obvious. The asset concerned was not, in a physical sense, 'lost'. The company's original cable between Cornwall and Bilbao began to show signs of failure in 1882 and broke down in 1884 and the company decided to lay down a new cable between those places (with money from an issue of debentures) rather than 'attempt to restore the original cable'; Bannatyne v Direct Spanish Telegraph Company, 1886. The breaching of one of the company's two submarine cables materially reduced their assets, such that they could not properly pay dividends until they had either accumulated enough money to replace the damaged cable, or had reduced their capital so as to bring their nominal capital into line with their surviving assets. The courts were not opposed to the principle of writing down both the assets and the totality of the share capital, but paid careful attention to the division of the write-down as between the ordinary shares and cumulative preference shares (that were preferential as to dividends but not to capital repayment).

On its formation in 1864 , the company had established general powers to reduce their issued capital and the directors' preferred course of action was to halve the share capital, ordinary and preference alike. Some preference shareholders took out an injunction and Bacon, ViceChancellor of the Court of Chancery, upheld their objections. He appeared to view, and certainly described, the preference shareholders as 'creditors' and their potential dividends as 'interest' and felt that accepting the right of directors to contract out of the agreement to pay the full amount of the preference dividends would be a way of 'cheating preference 
shareholders for the benefit of ordinary shareholders', that could invite other 'contrivances'. ${ }^{13}$ Bacon effectively asserted a distinction between all prior claims (including those of preference shareholders) on the one hand and the residual claims of the ordinary shareholders on the other; although preference shareholders are not creditors in the normal sense of the term, their entitlement to both dividends and repayment of capital is essentially circumscribed, such that any reduction of their defined capital would reduce their rights to both capital and dividends. The 'sacrifice' made by ordinary shareholders in capital reductions, on the other hand, was somewhat notional; as the holders of the residual claim, they stood to receive the entire surplus after all previous claims had been settled, both as regards revenues and capital. ${ }^{14}$

At appeal in November, 1886, the company claimed the preference shareholders were quasi partners, who should 'take their share of the loss of capital' and had no right 'at all times and under all circumstances [to] have $£ 6000$ a year'; instead their entitlement was to 10 per cent. on their share capital, as defined by the company. Lord Justice Cotton accepted this argument, did not find it problematic that the preference capital had been provided before the passing of the Companies Act 1877 (since the company's powers to reduce capital did not specifically exclude preference capital), saw the honesty of the directors proposed scheme as both evident and centrally important and accordingly supported the company's appeal and, therefore, their proposed capital reduction scheme.

\section{The treatment of the existing assets of firms in declining trades with complex shareholder class rights}

The circumstances of the Direct Spanish Telegraph Company were unusual. The loss of utility of the asset was unambiguous and rapid and arose from the physical deterioration of the asset concerned, with immediate and substantial effects upon the company's earning power. Situations in which assets continued to exist in good physical condition but were thought to have suffered a loss of utility, whether due to technological obsolescence or to changes in market conditions, were both commonplace and would raise issues that would be more difficult to resolve.

The judicial decisions in this difficult area took place in four cases concerning two major capital reduction schemes of Barrow Haematite Steel Company Ltd (BHS) in 1888 and 18991902. The company also obtained a private Act of Parliament after the court cases had been

\footnotetext{
13 Interest is not an apt word to express the return to which a shareholder is entitled in respect of shares paid up in due course and not by way of advance. Interest is compensation for delay in payment and is not accurately applied to the share of profits of trading'; Mr Justice Farwell, Bond v Barrow Haematite Steel Company, (1902).

14 See Mayson, French and Ryan 1996, p. 153; Ferran 1999, pp. 323-24; Pickering 1963.
} 
heard. BHS had been formed in 1864 by the Seventh Duke of Devonshire and his business associates, as one of a number of interlocking business ventures in Barrow-in-Furness. ${ }^{15}$ The Duke's dividend income rose from less than $£ 20,000$ in 1866 to more than $£ 150,000$ in 1874 , when he had the largest income of any aristocrat in the UK, but fell back to below £20,000 again in 1884, when the Devonshire family held more than one-third of the share capital. ${ }^{16}$ When early trial conversions of the local ores into Bessemer steel turned out 'most satisfactorily' (Chairman's comments to $1^{\text {st }}$ AGM of BHS 29 March 1865; National Archives of Scotland, Buccleuch papers, GD 224/144/5), a new steelworks was built on the waterfront at Barrow and its operations integrated with the existing ironworks. This produced large amounts of Bessemer steel, much of it to provide rails for the British, American and Canadian markets. ${ }^{17}$

The judicial decisions on capital maintenance were essentially judgments on the company's financial position and accounting practices and these are discussed below. In order to put the discussions in context, a summary of the company's main balance sheet items for the periods 1864 to 1873,1874 to 1888 and 1889 to 1902 are shown in Table 1 , together with profit and loss items for the same periods of time in Table 2 and selected financial ratios in Table 3.18

\section{TABLES 1-3 TO GO HERE}

The company's strategy was at first hugely successful. By 1873 it was the largest steel company in Britain, if not the world and in 1871-3 its total capital had earned $22.3 \%$ on average and its ordinary shares 28\%. ${ }^{19}$ Enormous dividends (see Table 2 col. 7 and Table 3 col. 3) had brought spectacular recovery to the Duke of Devonshire's previously stretched financial

15 It was registered as the Barrow Haematite Iron and Steel Co Ltd, although it generally traded as Barrow Haematite Steel Co Ltd; NA, BT31/1126c/44942-44944, BHS company papers. The development of these businesses was behind the spectacular growth of Barrow between 1845 and 1881; see Cannadine 1977; Pollard 1954, 1955; Pollard and Marshall 1953; Marshall 1958.

16 Cannadine 1977, pp. 94-96; Pollard 1955, p. 218. The Duke also received royalty payments on a deposit of more than eight million tons of best quality haematite ore that was found on his land in 1851 , the second largest ever find in the UK, and was used extensively by BHS; Marshall 1958, pp. 202-03.

17 The main iron ore deposit they owned contained more than eight million tons of best quality haematite ore; Barrow Records Office, BD HJ 163/3/1, Draft deed of agreement Barrow Haematite Steel Company Ltd (BHS) and Schneider and Hannay, 1864; 1st AGM of BHS, 29 March 1865; National Archives of Scotland, Buccleuch papers, GD 224/144/5; Marshall 1958, pp. 251-57, 343; Carr and Taplin 1962, p. 29.

18 The main data was obtained from: Barrow Records Office, BD HJ 163/3/1, Draft deed of agreement between BHS and Schneider and Hannay and the National Archives, BT31/1126c/44942-44944, Company files BHS for 1864; the National Archives of Scotland, Buccleuch papers; GD 224/144/5 BHS annual reports for 1865-82 and the Guildhall Library, London, annual reports filed with Stock Exchange, BHS for 1883-1902.

19 Pollard 1955, p. 215; Pollard and Marshall 1953, p. 122; Carr and Taplin 1962, p. 84. See Table 3 col. 1 1871-73 ((19.3+20.4+27.3)/3); Table 3 col. 2 1871-73 ((24.0+25.9+34.2)/3). 
affairs. This persuaded him to plough even more money back into the business, ${ }^{20}$ just as the boom was about to collapse. There followed a long period of uncertainty, pessimism and ... stagnation' in the iron and steel industry, with particular problems for Bessemer steel producers. $^{21}$

In the period $1874-82$, BHS issued $£ 700,000$ of ordinary shares and $£ 500,000$ of preference shares (some at $8 \%$ and the remainder at $6 \%$ ) to support a major programme of expansion and diversification. By 1887 they were in real difficulty; returns on capital in the three previous years were down to $1.1 \%,{ }^{22}$ no dividends had been paid despite very low charges for depreciation and there were no retained profits, or reserves (see Table 2 cols. 2 and 7; Table 1 cols. 2 and 3).

BHS’s first capital reduction was in 1888. The company had fixed assets of $£ 2.2 \mathrm{~m}$, but a diversification into coal mining had been both expensive (costing £603,000, 27.4\% of total fixed assets) and ill-judged and in 1888 the company's Annual Report announced the abandonment of their colliery in South Wales. It also stated that $£ 509,425$ was to be written off the assets. ${ }^{23}$ Losses are recognised when a reduced monetary value is placed on a particular asset. Normal losses on the operations of the business would then be charged against profits but the company viewed these losses as more strategic in nature. They did not want to charge them against profits as they were so large that they would probably block dividends for an indefinite period'; instead the company would seek the court's approval for a direct reduction in the share capital.

The directors' advised the ordinary shareholders that, following the Direct Spanish Telegraph Company decision (see above), any capital reduction should fall on preference as well as ordinary shareholders and that 'no legal distinction could be drawn' between the position of the preference shareholders in the two cases, although there were grounds to doubt this advice. ${ }^{24}$

20 Cannadine 1977, pp. 84-85, 94-96; Pollard 1954, 1955.

21 Birch 1967, p. 353; see also Pollard 1955, p. 216; Carr and Taplin 1962, pp. 95, 123-28.

22 See Table 3 col. 1 1885-87 $((0.9+1.2+1.3) / 3)$.

23 The asset write-off of $£ 509,425$ came under six heads: $£ 220,460$ for the 'depreciation in value' on the Yorkshire colliery (on which $£ 370,460$ had been spent); $£ 190,000$ on its South Wales colliery (£197,452 spent); $₫ 33,000$ on the Lancashire colliery (£34,815 spent); 55,000 reduction in coal royalties received in advance; $£ 27,291$ off general working stock; £33,674 off debtors; Annual report to 24th AGM of BHS, 14 March 1888, Guildhall Library, annual reports filed with Stock Exchange.

24 Annual report to 24th AGM of BHS p. 4, 14 March 1888, Guildhall Library, annual reports filed with Stock Exchange. In fact, in the earlier case, the articles of the company contained a power to reduce the capital at the point in time when the preference shares were issued and could therefore be seen as part of an agreed bargain. At BHS, the capital reduction was based upon a general entitlement in section 9 of the Companies Act 1867 and the subsequent amendment of the company's articles by special resolution in 1885, on which the preference shareholders could not vote; see re Barrow Haematite Steel Company, Chancery Division, 1888. The passing of the resolution in 1885 was itself caused directly by the situation 
at the collieries; the annual report to the members meeting in March indicated that counsels advice was being taken as to 'how best to deal with the capital loss' concerned; Annual report to 21 st AGM of BHS pp. 3-4, 16 March 1885, Guildhall Library, annual reports filed with Stock Exchange.

25 They also argued that the lack of available profits was partly due to imprudent ordinary dividend payments in 1873-83 totalling $£ 1,043,000$ (see Table 2, col. 7; although none had been had been paid in $1884-88$, when the arrears of preference dividends had reached $£ 124,000$ ) and that the ordinary shares had been increased by $£ 500,000$ through bonus issues out of profits in 1867-74, without which there would be 'no necessity for the reduction of capital' (see Table 2, col. 8).

The preference shareholders raised several objections, two of which went to the heart of the capital maintenance issue. ${ }^{25}$ Firstly, that there had been 'no corresponding revaluation of such portions of the property of the company as have increased in value' and secondly that, since 'for some years nothing was written off for depreciation of assets ... the effect of the proposed reduction will be to make the preference shareholders contribute to the depreciation, while the ordinary shareholders have had all the benefit of the company's prosperity' (re Barrow Haematite Steel Company, 1888). There was no legal requirement at this time for depreciation to be charged against profits and individual businessmen were able to retain significant discretion over the ways in which the profits of their business were defined and to vary the accounting practices, notably regarding fixed assets, to the changing circumstances of their trade (Edwards 1980, p. 242). BHS was no different. During the period of high profits from 1866-73 it charged depreciation averaging $£ 33,600$ a year but in 1874-78 it charged nothing. Thereafter its depreciation charges were generally small (see Table 2 col. 2). Over the period 1866-84 its depreciation charges averaged $£ 28,200$ p.a. (see Table 2 col. 2) on fixed assets averaging $£ 1,417,700$ (see Table 1 col. 7 ), at an average annual rate of $2.0 \%$. Clearly, these charges did not recognise the wearing out of the assets concerned, particularly in an industry in which there was considerable technological change. The financial statements did not indicate any active policy of valuing the assets according to expert trade valuations, except in times of crisis.

Mr. Justice North did not entirely accept the company's claims but he did decide that 'there was nothing unfair or inequitable' in their proposals and that the preference shareholders should therefore take their share of those losses (and thereby accept an immediate reduction in their future entitlement to dividends; re Barrow Haematite Steel Company, 1888). The scheme was considered as a whole and little attention was apparently paid to any accounting issues or to the components of the asset write-off; thus all six write-offs were accepted as capital, not revenue (see above). While the South Wales and Lancashire collieries were abandonments, the Yorkshire colliery was not (and would still be owned and used by BHS in the 1930s). The other three items were all relatively normal adjustments to current assets, including a reduction in the value of stock due to 'improved systems of manufacture' and for a probable bad debt 
(Annual report to 24th AGM of BHS pp. 3-4, 14 March 1888, Guildhall Library, annual reports filed with Stock Exchange)!

Capital employed at BHS had been reduced in 1888 to $£ 2.2 \mathrm{~m}$, by writing down both classes of share capital by a quarter, and it remained at approximately that level for the rest of the century, during which period returns on capital employed averaged $3.25 \%$, well below the rate of interest on debt and despite depreciation charges that averaged slightly less than $1 \%$ of fixed asset book values. ${ }^{26}$ In 1899, the directors announced that a further reduction of capital was 'inevitable'; many of the fixed assets had not been written down in the earlier scheme, as they had not 'foreseen that the company would have to contend for some years with a serious depression in the iron and steel trade'. Accordingly they proposed the writing down of their fixed assets by $£ 764,138$, held in a Depreciation Suspense Account as a separate asset and recommending that all classes of share capital be halved (Letter to BHS shareholders from the directors of 14 November 1899; Guildhall Library, annual reports filed with Stock Exchange). ${ }^{27}$

Many of the preference shareholders opposed this, lest circumstances should arise under which the company would again make large profits (quoted in letter to BHS shareholders from the directors of 29 March 1900; Guildhall Library, annual reports filed with Stock Exchange). The situation also differed somewhat from 1888; no equity dividends had been paid since 1892, as the directors would not recommend any 'until the capital reduction proposal were resolved', and retained profits in 1901 were the highest in the company's history, despite depreciation charges in 1900 and 1901 that were the highest for twenty years (see Table 1 cols. 2 and 3 and Table 2 col. 2)!

In court, Mr. Justice Cozens-Hardy explained that the case law in this area had changed in the last twelve years (he referred specifically to Lee v Neuchatel Asphalte Company, 1889 and Verner $v$ General and Commercial Investment Trust, 1894), such that, where part of the fixed capital of a company had been lost, it could still pay dividends out of its current profits. In view

26 The ordinary share capital was reduced by $£ 375,000$ and the preference shares by the remaining $£ 134,425$. Ex post, the preference shareholders came out of the 1888 reductions quite well; in 1888-1899 they received dividends of $£ 330,000$, which greatly reduced the arrears of their dividends, whereas the ordinary shareholders received only two small dividends, each of $2.5 \%$; see Table 2 , cols. 6-7). The returns on capital employed were from 1889-1899 inclusive; see Table 3 col. 1. The rates of return would of course have been even lower had the capital figures not been reduced in 1888. The average annual charge for depreciation for 1889-99 (see Table 2 col. 2) was £17,700; the average fixed asset book value for the same period was $£ 1,821,000$ (see Table 1 col. 7).

27 Of the fixed asset reductions, £214,016 were 'realised losses'; $£ 146,657$ on the surrender of some iron ore mines, $£ 28,240$ on blast furnaces that had been pulled down and $£ 39,119$ from the sale of houses and land. The remaining $£ 550,122$ was based on the estimates of 'expert valuers'. The capital consisted of $£ 1,125,000$ in ordinary shares and $£ 28,275$ in $8 \%$ and $£ 375,000$ in $6 \%$ preference shares; annual report to 37th AGM of BHS, 2 April 1901; Guildhall Library, annual reports filed with Stock Exchange. 
of the 'state of the law as now recognised' he saw 'no necessity for a reduction', particularly in the light of the un-appropriated profits and reserves, and did not want to act on the 'balance of speculative expert evidence as to the value of mining property'. He thought the business could still be carried on as it was and felt that reducing the capital would 'in no way affect the business of the company, or benefit the company looked on as a whole'; instead he believed that its effect would be an injustice to the preference shareholders, taking dividends out of the pockets of the preference shareholders and giving them to the ordinary shareholders, in 'derogation of the original bargain they made' (re Barrow Haematite Steel Company, 1900). The judge agreed that the directors had to keep 'true and honest accounts', but thought they could 'honestly and properly prepare a balance-sheet shewing or implying a loss of capital, and at the same time may honestly and properly prepare a loss and profit account shewing a balance available for dividend'. The judge's comment that 'reserves and un-appropriated profit ought to be considered as available assets' also suggests that he was not clear on the differences between the two sides of the balance sheet and, therefore, whether capital meant the ownership inputs or the company's assets, whether fixed or circulating; re Barrow Haematite Steel Company, 1900.

When the case went to appeal, the appeal judges indicated that they were unconvinced that capital had been lost to the extent of more than $£ 764,000$ and that the decision, which they upheld, relied primarily on a view that the proposed reductions would not be fair and equitable as between the preference and the ordinary shareholders (re Barrow Haematite Steel Company, 1901). A year later, these matters came to court again (in Bond $v$ Barrow Haematite Steel Company, 1902) when the preference shareholders sought the payment of their fixed, cumulative preference dividends, on the grounds that 'the losses arising out of the flooding of mines and miners cottages could be ignored in calculating the dividend fund'.

Mr. Justice Farwell accepted that BHS had suffered realised losses of capital of $£ 214,016$, noted that the case, as put forward by the preference shareholders did not require him to make any distinction between realized and estimated losses and thought 'it would serve no useful purpose' if he did. What seemed more important, following Lindley, was the argument that, although in some cases fixed capital might be sunk and lost, without precluding the payment of a dividend, circulating capital must be kept up. Mining was not the main business of the company but was merely there to supply iron ore to the main business; "by way of economy they acquired the leases of the surrendered mines in order to supply themselves with their own ore instead of buying it as required', while the blast furnaces and cottages were merely ancillary such that the money invested in these items could be 'properly regarded in this company as circulating capital'. The mines were 'drowned out and the cost of pumping them 
out was prohibitive. The company, therefore, surrendered the leases, pulled down the blast furnaces, and sold the cottages connected therewith' (the $£ 214,016$ was the 'realised losses of $£ 146,657$ on the surrender of some iron ore mines, $£ 28,240$ on blast furnaces that had been pulled down and £39,119 from the sale of houses and land). Mr. Justice Farwell noted that the courts had often over-ruled directors who proposed to pay dividends, but he was not aware of 'any case in which the Court has compelled them to pay when they have expressed their opinion that the state of the accounts did not admit of any such payment. In a matter depending on evidence and expert opinion, it would be a very strong measure for the Court to override the directors in such a manner'. Instead, the courts upheld the fundamental right of directors to propose maximum dividends, whether on ordinary or preference shares. ${ }^{28}$

He also saw important differences between the statutory requirement that "dividends must not be paid out of capital" and a clause often included in company articles that "dividends may only be paid out of profits" and saw nothing in the statutes requiring a company to keep up the value of its capital assets to the level of its nominal capital. ${ }^{29}$ The real question, of whether there were profits available for distribution, was seen as 'difficult' and issues concerning the losses that could 'be properly charged to capital, and what to income, was a matter for businessmen to determine', as there was no single definition of the word "profits" which would fit all cases. ${ }^{30}$

These decisions and comments persuaded the company that its assets could and should be written down, and to seek a substantial writing down of all classes of the share capital but to seek this through a route other than the courts. BHS reached agreement with the preference shareholders on a revised arrangement that would made good the arrears of preference dividends and protect their dividend position in the long-term and was then able to obtain an

28 This is still the leading case on the principle that 'no dividend is payable on a company's shares, even on preference shares, unless and until the company has decided to pay one'; Mayson, French and Ryan 1996, pp. 282-83.

29 See also Lindley L.J. in Lee v. Neuchatel Asphalte Co., 1889. BHS's article 96 said 'no dividend shall be payable except out of the profits arising from the business of the company'.

30 Of the two he identified, Professor Marshall's and Lord Justice Lindley's, the first clearly looked to an annual comparison of both fixed and circulating capital. Thus, Marshall said that "when a man is engaged in business, his profits for the year are the excess of his receipts from his business during the year over his outlay for his business; the difference between the value of his stock and plant at the end and at the beginning of the year being taken as part of his receipts or as part of his outlay, according as there has been an increase or decrease of value." 'Stock and plant' clearly includes both fixed and circulating capital. Following Mill, circulating capital, 'fulfils the whole of its office in the production in which it is engaged, by a single use' whereas fixed capital, 'exists in a durable shape and the return to which is spread over a period of corresponding duration"; Marshall 1890, pp. 134, 142. The second, Lindley's, argued that 'fixed capital may be sunk and lost, and yet the excess of current receipts over current payments may be divided', as long as the floating or circulating capital was 'kept up' (Lee $v$. Neuchatel Asphalte Co., 1889; Verner v. General and Commercial Investment Trust, 1894). 
Act of Parliament later that same year reducing each class of share capital by $40 \% .{ }^{31} \mathrm{By}$ December 1902, the assets had been 'depreciated' by the originally scheduled amount, with a substantial contribution from profit and loss (to make good the reduction in the amount from share capital) and this still left enough distributable profits for a $3 \%$ dividend to the ordinary shareholders, the first such payment for ten years. ${ }^{32}$

\section{Discussion and conclusions}

This paper starts from Blair's argument that the unique manner in which incorporation permitted organizers to lock-in financial capital' was central to the importance of companies as a business form in the nineteenth century (Blair 2003a, p. 387). This brought substantial economic benefit, since capital could then be readily spent on the 'long-term, highly specific investments' on which the modern industrial economy would be based (Blair 2003a, p. 390). The precise level and pattern of benefit would vary between countries, according to the way that their legal systems defined capital lock-in, or maintenance.

In England, although the formation of limited liability companies by simple registration was available from 1855, legislation was slow to delineate the precise meaning of capital maintenance -- 'distributable profits', for example, were not defined by legislation until 1980 and judicial and other influences were the more important.

A substantial literature has considered a wide range of late nineteenth century 'dividend cases', and their implications for the development of the capital maintenance concept. This paper's intention, as set out in the introduction, is to question whether this literature adequately reflects judicial influences on the development of the capital maintenance doctrine in England during this period of time.

Its conclusion is that they do not. This is not because of any particular inadequacies in these papers - they are typically erudite, interesting and well argued - but because the capital maintenance concept was shaped by both immediate dividend payment issues and by the

\footnotetext{
${ }^{31}$ See Parliamentary Archives, House of Lords, Barrow Haematite Steel Co Ltd Act 1902, pp. 4-5. The Companies Act 1862 (25\&26 Vict. c.89, s.162) did give companies the power to purchase their own shares with statutory authorization.

32 The ordinary shares and 6\% preference shares were written down from $£ 7.5$ to $£ 4.5$ and the $8 \%$ preference shares from $£ 75$ to $£ 45$, the capital in total from $£ 1,528,275$ to $£ 916,965$, with the remaining $£ 152,828$ (of the $£ 764,138$ reduction in assets) transferred from Profit and Loss. The $6 \%$ preference shares were to receive a (cumulative) annual dividend of $6 \%$ on their reduced capital, with further dividends to be paid at half the rate of any ordinary dividends. The $8 \%$ preference shareholders were to receive a (cumulative) annual dividend of $13.3 \%$ on their reduced capital to maintain their previous annual dividend amount; annual report to 39th AGM of BHS, 18 March 1903; Guildhall Library, annual reports filed with Stock Exchange.
} 
longer-term dividend implications of capital reduction schemes. The paper's central argument is, therefore, that even excellent analyses of dividend cases will not fully explain the evolution of the capital maintenance concept. In support of this argument, it identifies and discusses the issues that arose in an important set of capital reduction cases heard by the courts in the second half of the nineteenth century. There is no implicit claim that the treatment provided in this paper is comprehensive but it does identify an area for further empirical work and an appropriate methodology that can be used, in the hope that this will promote further analysis and debate on the evolution of this important concept.

Ardern and Aiken, in a recent 'accounting history of capital maintenance', which reviews the relevant literature in a comprehensive and scholarly manner, saw 'disputes concerned with measurement issues ... as centred on the recurring debate over the amount of profits available for the purposes of dividend distribution' (Ardern and Aiken 2005, p. 24). A section headed 'Alternative Definitions of Capital Maintenance' identified two broad approaches, the surplus approach (where the profit and loss account was secondary to a comparison of net asset valuations at the start and end of the period) and another, where the profit and loss account 'provides the primary evidence of the availability of profit', in both cases to determine the extent to which dividends could be paid (2005, pp. 28-29). No consideration was given in this or any other section to the effects of capital reduction schemes on the capital maintenance concept.

Although the term 'capital maintenance' is so widely used and is in principle so simple, the uncertainties of business operations and asset valuation processes meant that the concept could not be applied in any literal way; instead what emerged was a requirement that capital should not be returned to the shareholders before the business was liquidated. The decision of the House of Lords in Trevor $v$ Whitworth in 1887, making the redemption or purchase of a company's own shares illegal, meant that capital could only be returned to the shareholders by dividend payments where the net value of assets had not been maintained. This could arise under two judicial procedures; firstly if the courts agreed that certain losses could be disregarded for the purpose of calculating the dividend fund (i.e. the maximum possible dividend) or, secondly, if they agreed that certain capital losses could be deducted from share capital rather than charged to profit and loss. The first mechanism (the 'dividend cases'), addressed the legitimacy of immediate dividend payments and has been widely discussed, while the second (the 'capital reduction cases') affected the company's ability to pay dividends out of future surpluses, but has received far less attention in the literature to date.

There were significant overlaps between the two procedures - the judicial decisions in Lee $v$. Neuchatel Asphalte Co. (1889) and Verner v. General and Commercial Investment Trust (1894) in 
particular were sufficiently important to have major effects on both - but some of the issues that the courts considered in the capital reduction cases had important effects on the capital maintenance doctrine and on shareholder class rights. The difficult economic circumstances faced by many companies during the late nineteenth century encouraged the putting forward of capital reduction schemes but the increased importance of preference shares meant that cases often raised two simultaneous problems; a primary one as to whether the asset losses should be charged to capital (i.e. set against share capital) or to revenue (charged to the profit and loss account) and the secondary issue of whether losses that were to be treated as capital, should be borne by the ordinary shareholders alone or by the preference shareholders as well. The first issue raised directly the capital maintenance problem and the second raised further issues of equity and fairness, since ordinary and preference shareholders had differing rights as to both dividend entitlement and capital repayment.

The position of the courts was difficult. The priority of protecting creditors was always recognized, although, as Edwards points out, even if solvency tests work satisfactorily in the short-term they will not maintain the capital of the business in the long-term (Edwards 1989, p. 182. See also Mason 1932, pp. 64-65). There was a clear perception, during difficult times in many industries, that if capital were maintained 'at all costs' the likely outcome would be to 'paralyze the trade of the country' (see Lindley's remarks in Verner (1894); also Ardern and Aiken 2005, pp. 42-47) but the successive issues that arose in the capital reduction cases were not handled consistently or well.

It is quite apparent that 'capital' initially meant shareholders monies, since the applications to the courts were not for the right to write down asset values; depreciating assets was of course not a requirement at the time but was still something that companies were entitled to do without specific consent. In 1876, although the value of the assets of the Ebbw Vale Steel, Iron and Coal Company Ltd had apparently fallen, the court would not sanction a cut in the share capital as the proposal was 'not an actual reduction, because the capital has (already) been lost. It is merely acknowledging that to be lost which is lost'. Instead, the courts could only allow actual reductions of capital, which they indicated could include a cancellation of the obligation of the shareholders for further calls on their shares (re Ebbw Vale Steel, Iron, and Coal Company, 1877). A Companies Act later that year then allowed paid up share capital to be reduced where the assets representing it had been lost but subsequent judicial decisions extended this considerably to circumstances under which the assets had not been 'lost', although they might have lost value.

The first signs of the difficulties of fitting preference shares to a capital maintenance doctrine 
shaped by more fundamental differences between creditors and ordinary shareholders emerged in 1886, in a case in which a substantial loss of asset value was apparent. The directors' intention was to halve the ordinary and preference share capital, but Bacon, Vice-Chancellor of the Court of Chancery, upheld an injunction against this, effectively asserting a distinction between all prior claims (including those of preference shareholders) on the one hand and the residual claims (both for dividends and capital repayment) of the ordinary shareholders on the other. Lord Justice Cotton over-ruled this in November, 1886, seeing the preference shareholders position as more akin to that of the ordinary shareholders than to the creditors.

When the first BHS capital reduction scheme was heard, the courts seemed more concerned with the pressing but essentially secondary issue of fairness as between classes of shareholders than the primary issue of whether the losses of asset value should be directly charged against share capital or not. This matters because the essential condition of trade is that changes in asset value take place all the time, whether recognizable on the basis of individual transactions (e.g. the cost of acquired goods that had been re-sold) or as part of a gradual process (the wear and tear of a machine).

Mr. Justice North accepted all six proposed asset write-offs as capital, not revenue, even though three were relatively normal adjustments to current assets and a fourth was merely the unexpected cost of sinking a colliery in Yorkshire that BHS would use until the 1930s. He saw 'nothing unfair or inequitable' in their proposals and thought the preference shareholders capital should take its share of those losses (see above and Table 1, cols. 1, 4, 7-8).

In 1900, the serial inconsistency of the judiciary in the capital reduction cases would be taken a good deal further, following the decisions in Lee $v$ Neuchatel Asphalte Company (1889) and Verner v General and Commercial Investment Trust (1894). Mr. Justice Cozens-Hardy now clearly saw capital as being on what can be called the 'other (assets) side of the balance sheet', since the key distinction was now (following Lindley) apparently between fixed and circulating capital. He also refused to accept the company's capital reduction proposal as warranted, and was concerned that it would be an injustice to the preference shareholders, taking dividends out of the pockets of the preference shareholders and giving them to the ordinary shareholders, in 'derogation of the original bargain they made'. ${ }^{3}$

33 The judge's further comment that 'reserves and un-appropriated profit ought to be considered as available assets' suggests an even greater degree of confusion; re Barrow Haematite Steel Company, 1900. 
The decision in the Lee case, to re-define capital in terms of asset categories (circulating and fixed) rather than shareholder inputs may have sufficed for dividend decisions ${ }^{34}$ but the BHS cases in 1900-01 raised the additional issue of whether there was any meaningful distinction between realised and non-realised reductions in asset value. This was viewed by the judiciary as secondary to the main circulating-fixed distinction but the actual decisions made in the court cases of 1900-02 meant that three categories of fixed asset reductions (the realised losses on surrendered iron ore mines $(£ 146,657)$, on closed down blast furnaces $(£ 28,240)$ and on sold houses $(£ 39,119))$ along with $£ 550,122$ of write-down's in the iron ore mines, iron works, steel works, engineers shops and buildings, waterworks, reservoirs, wireworks and land and house property', consistent with 'expert' valuations (letter to the shareholders of Barrow Haematite, 14 November 1899, Guildhall Library, annual reports filed with Stock Exchange) were all to be treated as revenue not capital.

The directors of BHS had determined, when putting forward their capital reduction scheme, that the assets and ownership capital on the company Balance Sheet should be brought into line with business 'realities'. Based on previous judicial decisions they had every expectation of being able to reduce their future payments of preference dividends but, given the judicial position that emerged, they decided to forego this (by negotiating an agreed position with the preference shareholders that maintained the latter's dividend entitlements) and proceed by the unusual mechanism of a Parliamentary Private Act. In their judgment, this had become the most sensible way for businesses with highly specific assets and preference capital to cope with their capital maintenance problems.

The intention of this paper has been to show that no account, however satisfactory, of the nineteenth century 'dividend cases' can reveal the full development of the capital maintenance concept during the same period of time. The capital maintenance issues that were provoked by a series of capital reductions in the same time period may or may not be seen as more important but they were clearly significant, different and developed in a different way.

The paper does not argue that this reflects any particular intention or perspective on the part of the governments of the time, who found it hard to deal with the industrial circumstances of

\footnotetext{
${ }^{34}$ As Marx and others have shown, the distinction is actually rather relative and unreliable; fixed capital also 'circulates', even if its circulation time is much longer. This being so, it is not difficult to see depreciation charges as a mechanism to estimate the extent to which the 'fixed' had become 'circulating' and therefore properly chargeable against current revenues. See Marx (1978, Vol. 1, pp 760-61) including the comment that 'political economy since the time of Adam Smith has confusedly mixed up the determining characteristics contained in these categories [variable and constant capital] with the merely formal distinction, arising out of the process of circulation, between fixed and circulating capital' (p. 760). See also Vol. 2 (pp. 237-61), including the argument that 'the peculiar circulation of fixed capital gives rise to a peculiar turnover. The portion of value that it loses in its natural form by wear and tear circulates as a value portion of the product' (p. 242). See also French 1977, pp. 314-22; Yamey 1941, pp. 280-81; Bryer 1998, for a discussion of the distinction between circulating and fixed assets and Napier (2015) for an explanation of the Lee case as the survival of aristocratic attitudes to capital and income.
} 
the late nineteenth century, particularly in the iron and steel industry, at a time when the basic notion of capital maintenance was complicated by the emergence of preference shares as an important source of capital. The legislature refused to provide a framework that would satisfactorily reconcile the competing interests in relatively new companies and the judiciary was left, in individual cases, to find a satisfactory way forward. Views may differ on their success in the dividend cases but this paper has shown that an important set of capital reduction schemes were handled in a thoroughly inconsistent, even logically incoherent manner, that can have done nothing to improve resource allocation decisions in the English economy of the time. 
Table 1: Barrow Haematite Balance Sheet items, 1864-1902 (£000)
(1)
(2)
(3)
(4)
(5)
(6)
(7)
(8)
(9)

Ordinary Retained General Pref. Debent. Total Fixed Other Total shares profits reserve shares

capital assets net assets assets

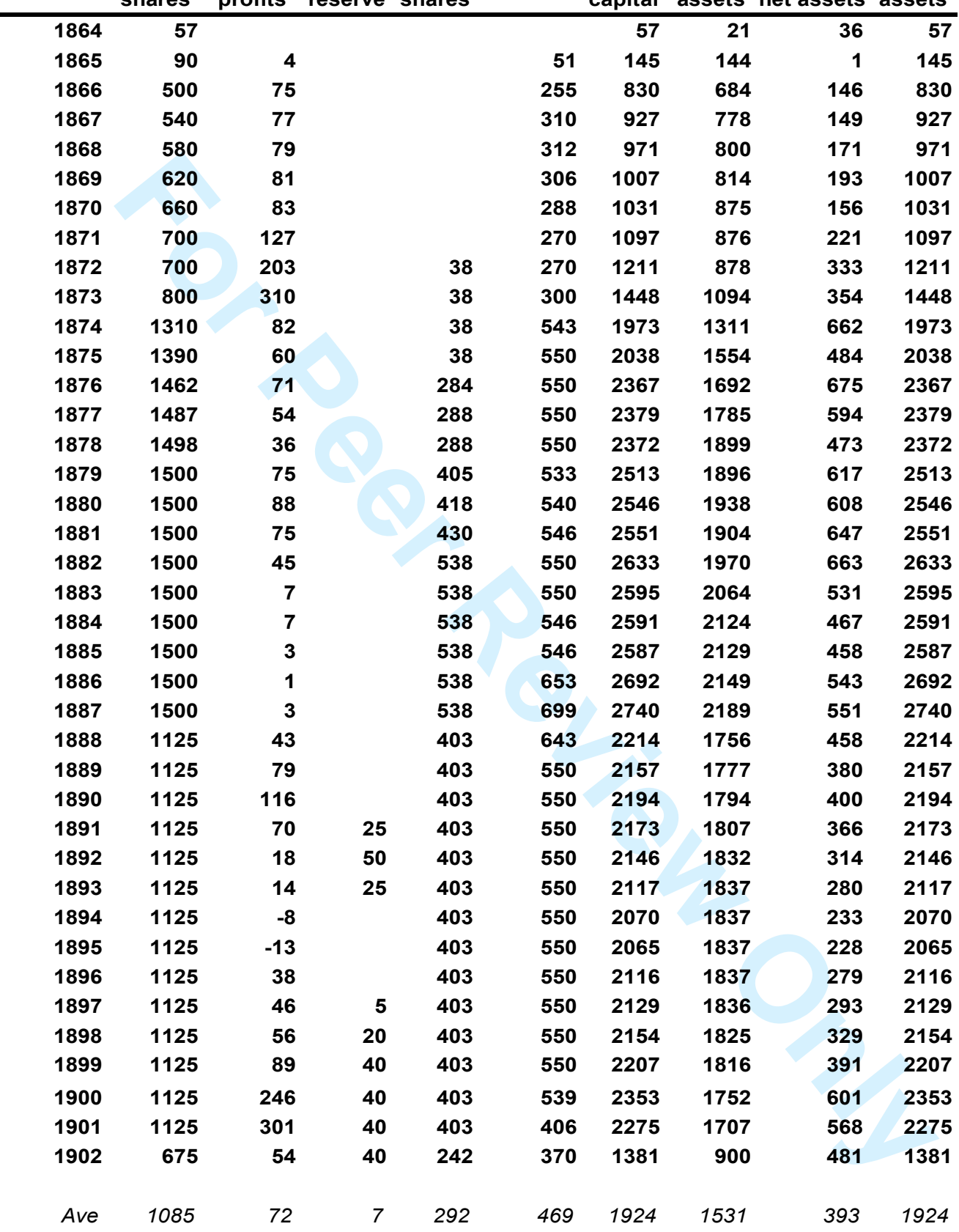

Sources: National Archives, BT31/1126c/44942-44944, Company files BHS for 1864

National Archives of Scotland, Buccleuch papers; GD 224/144/5 BHS annual reports for $1865-82$

Guildhall Library, London, annual reports filed with Stock Exchange, BHS for 1883-1902.

Notes: in col (4) Pref. $=$ Preference

in col (5) Debent. = Debentures

in col (8) Other net assets $=$ Current assets - current liabilities 
Table 2: Barrow Haematite Profit and Loss items, 1865-1902 (£000)

\begin{tabular}{|c|c|c|c|c|c|c|c|c|c|c|c|}
\hline & $\begin{array}{c}\text { (1) } \\
\text { Trading } \\
\text { profit }\end{array}$ & $\begin{array}{c}\text { (2) } \\
\text { Deprec. }\end{array}$ & $\begin{array}{c}\text { (3) } \\
\text { Debent. } \\
\text { interest }\end{array}$ & $\begin{array}{c}(4) \\
\text { Net } \\
\text { profit }\end{array}$ & $\begin{array}{c}\text { (5) } \\
\text { Tfr to } \\
\text { gen res }\end{array}$ & $\begin{array}{c}(6) \\
\text { Pref } \\
\text { divis }\end{array}$ & $\begin{array}{c}(7) \\
\text { Ord } \\
\text { divis }\end{array}$ & $\begin{array}{c}\text { (8) } \\
\text { Bonus } \\
\text { issues }\end{array}$ & $\begin{array}{c}\text { (9) } \\
\text { Ret. for } \\
\text { year }\end{array}$ & $\begin{array}{c}\text { (10) } \\
\text { Ret pr } \\
\text { b.f. }\end{array}$ & $\begin{array}{c}\text { (11) } \\
\text { Ret pr } \\
\text { c.f. }\end{array}$ \\
\hline 1865 & 7 & 0 & -3 & 4 & & & & & 4 & & 4 \\
\hline 1866 & 188 & -50 & -13 & 125 & & & -54 & & 71 & 4 & 75 \\
\hline 1867 & 159 & -38 & -16 & 106 & & & -64 & -40 & 2 & 75 & 77 \\
\hline 1868 & 138 & -12 & -16 & 110 & & & -68 & -40 & 2 & 77 & 79 \\
\hline 1869 & 167 & -38 & -15 & 114 & & & -72 & -40 & 2 & 79 & 81 \\
\hline 1870 & 151 & -19 & -14 & 118 & & & -76 & -40 & 2 & 81 & 83 \\
\hline 1871 & 231 & -19 & -14 & 199 & & & -115 & -40 & 44 & 83 & 127 \\
\hline 1872 & 304 & -57 & -14 & 234 & & -3 & -155 & & 76 & 127 & 203 \\
\hline 1873 & 431 & -36 & -15 & 380 & & -3 & -170 & -100 & 107 & 203 & 310 \\
\hline 1874 & 156 & 0 & -27 & 129 & & -3 & -154 & -200 & -228 & 310 & 82 \\
\hline 1875 & 99 & 80 & -28 & 152 & & -3 & -171 & & -23 & 82 & 60 \\
\hline 1876 & 102 & 0 & -28 & 75 & & -3 & -61 & & 11 & 60 & 71 \\
\hline 1877 & 144 & 0 & -28 & 117 & & -3 & -131 & & -18 & 71 & 54 \\
\hline 1878 & 135 & 0 & -28 & 108 & & -48 & -78 & & -19 & 54 & 36 \\
\hline 1879 & 108 & -22 & -27 & 59 & & -20 & & & 39 & 36 & 75 \\
\hline 1880 & 88 & -22 & -27 & 39 & & -26 & & & 13 & 75 & 88 \\
\hline 1881 & 254 & -100 & -27 & 127 & & -27 & -113 & & -13 & 88 & 75 \\
\hline 1882 & 166 & -20 & -27 & 119 & & -29 & -120 & & -30 & 75 & 45 \\
\hline 1883 & 67 & 0 & -27 & 40 & & -33 & -45 & & -38 & 45 & 7 \\
\hline 1884 & 82 & -22 & -27 & 33 & & -33 & & & 0 & 7 & 7 \\
\hline 1885 & 45 & -22 & -27 & -4 & & & & & -4 & 7 & 3 \\
\hline 1886 & 36 & -5 & -33 & -2 & & & & & -2 & 3 & 1 \\
\hline 1887 & 52 & -16 & -34 & 2 & & & & & 2 & 1 & 3 \\
\hline 1888 & 94 & -22 & -32 & 40 & & & & & 40 & 3 & 43 \\
\hline 1889 & 134 & -23 & -32 & 79 & & -43 & & & 36 & 43 & 79 \\
\hline 1890 & 161 & -19 & -28 & 114 & & -77 & & & 37 & 79 & 116 \\
\hline 1891 & 133 & -30 & -28 & 75 & -25 & -68 & -28 & & -46 & 116 & 70 \\
\hline 1892 & 75 & -22 & -27 & 26 & -25 & -25 & -28 & & -52 & 70 & 18 \\
\hline 1893 & 29 & -7 & -26 & -4 & 25 & -25 & & & -4 & 18 & 14 \\
\hline 1894 & 0 & -10 & -25 & -35 & 25 & -12 & & & -22 & 14 & -8 \\
\hline 1895 & 27 & -7 & -25 & -5 & & & & & -5 & -8 & -13 \\
\hline 1896 & 113 & -35 & -27 & 51 & & & & & 51 & -13 & 38 \\
\hline 1897 & 85 & -14 & -28 & 43 & -5 & -30 & & & 8 & 38 & 46 \\
\hline 1898 & 94 & -16 & -28 & 50 & -15 & -25 & & & 10 & 46 & 56 \\
\hline 1899 & 118 & -12 & -28 & 78 & -20 & -25 & & & 33 & 56 & 89 \\
\hline 1900 & 247 & -62 & -28 & 157 & & & & & 157 & 89 & 246 \\
\hline 1901 & 119 & -40 & -24 & 55 & & & & & 55 & 246 & 301 \\
\hline 1902 & 110 & -190 & -19 & -99 & & -121 & -27 & & -247 & 301 & 54 \\
\hline Ave & 124 & -24 & -23 & 77 & -1 & -18 & -44 & -13 & 1 & 70 & 72 \\
\hline
\end{tabular}

Sources: as Table 1

Notes: in col (2) Deprec. $=$ Depreciation

in col (3) Debent. $=$ Debentures

in col (5) gen. res. = general reserve

in col (6) Pref. $=$ Preference

in col (7) Ord. = Ordinary

in col (9) Ret. = Retained

in col (10) Ret pr b.f. = Retained profits brought forward

in col (11) Ret pr c.f. = Retained profits carried forward 
Table 3: Barrow Haematite financial ratios, 1865-1902 (\%)

\begin{tabular}{|c|c|c|c|c|c|c|c|}
\hline & $\begin{array}{c}\text { (1) } \\
\text { RoCE } \\
\text { PBIT/CE }\end{array}$ & $\begin{array}{c}\text { (2) } \\
\text { RoE } \\
\text { NP/Eq }\end{array}$ & $\begin{array}{c}\text { (3) } \\
\text { RoOrd } \\
\text { Div/Ord }\end{array}$ & $\begin{array}{c}\text { (4) } \\
\text { RoPref } \\
\text { Div/Pref }\end{array}$ & $\begin{array}{c}\text { (5) } \\
\text { RoDeb } \\
\text { Int/Deb }\end{array}$ & $\begin{array}{c}\text { (6) } \\
\text { Pref\&Deb } \\
\text { to Cap Emr }\end{array}$ & $\begin{array}{c}\text { (7) } \\
\text { Deprec } \\
\text { to fix ass }\end{array}$ \\
\hline 1865 & 4.8 & 4.7 & & & -5.0 & 35.2 & \\
\hline 1866 & 16.6 & 21.8 & 10.8 & & -5.0 & 30.7 & 7.3 \\
\hline 1867 & 13.1 & 17.1 & 11.9 & & -5.0 & 33.4 & 4.9 \\
\hline 1868 & 13.0 & 16.8 & 11.7 & & -5.0 & 32.1 & 1.5 \\
\hline 1869 & 12.8 & 16.2 & 11.6 & & -5.0 & 30.4 & 4.7 \\
\hline 1870 & 12.8 & 15.8 & 11.5 & & -5.0 & 27.9 & 2.2 \\
\hline 1871 & 19.3 & 24.0 & 16.4 & & -5.0 & 24.6 & 2.2 \\
\hline 1872 & 20.4 & 25.5 & 22.1 & -7.9 & -5.0 & 25.4 & 6.5 \\
\hline 1873 & 27.3 & 34.0 & 21.3 & -7.9 & -5.0 & 23.3 & 3.3 \\
\hline 1874 & 7.9 & 9.0 & 11.8 & -7.9 & -5.0 & 29.4 & 0.0 \\
\hline 1875 & 8.8 & 10.2 & 12.3 & -7.9 & -5.0 & 28.9 & -5.1 \\
\hline 1876 & 4.3 & 4.7 & 4.2 & -1.1 & -5.0 & 35.2 & \\
\hline 1877 & 6.1 & 7.4 & 8.8 & -1.0 & -5.0 & 35.2 & \\
\hline 1878 & 5.7 & 3.9 & 5.2 & -16.7 & -5.0 & 35.3 & \\
\hline 1879 & 3.4 & 2.5 & & -4.9 & -5.1 & 37.3 & 1.2 \\
\hline 1880 & 2.6 & 0.8 & & -6.2 & -5.0 & 37.6 & 1.1 \\
\hline 1881 & 6.0 & 6.3 & 7.5 & -6.3 & -4.9 & 38.3 & 5.3 \\
\hline 1882 & 5.5 & 5.8 & 8.0 & -5.4 & -4.9 & 41.3 & 1.0 \\
\hline 1883 & 2.6 & 0.5 & 3.0 & -6.1 & -4.9 & 41.9 & \\
\hline 1884 & 2.3 & 2.0 & & -6.1 & -4.9 & 41.8 & 1.0 \\
\hline 1885 & 0.9 & -0.3 & & & -4.9 & 41.9 & 1.0 \\
\hline 1886 & 1.2 & -0.1 & & & -5.1 & 44.2 & 0.2 \\
\hline 1887 & 1.3 & 0.1 & & & -4.9 & 45.1 & 0.7 \\
\hline 1888 & 3.3 & 3.4 & & & -5.0 & 47.2 & 1.3 \\
\hline 1889 & 5.1 & 3.0 & & -10.7 & -5.8 & 44.2 & 1.3 \\
\hline 1890 & 6.5 & 3.0 & & -19.1 & -5.1 & 43.4 & 1.1 \\
\hline 1891 & 4.7 & 0.6 & 2.5 & -16.9 & -5.1 & 43.9 & 1.7 \\
\hline 1892 & 2.5 & 0.1 & 2.5 & -6.2 & -4.9 & 44.4 & 1.2 \\
\hline 1893 & 1.0 & -2.5 & & -6.2 & -4.7 & 45.0 & 0.4 \\
\hline 1894 & -0.5 & -4.2 & & -3.0 & -4.5 & 46.0 & 0.5 \\
\hline 1895 & 1.0 & -0.4 & & & -4.5 & 46.2 & 0.4 \\
\hline 1896 & 3.7 & 4.4 & & & -4.9 & 45.0 & 1.9 \\
\hline 1897 & 3.3 & 1.1 & & -7.4 & -5.1 & 44.8 & 0.8 \\
\hline 1898 & 3.6 & 2.1 & & -6.2 & -5.1 & 44.2 & 0.9 \\
\hline 1899 & 4.8 & 4.4 & & -6.2 & -5.1 & 43.2 & 0.7 \\
\hline 1900 & 7.9 & 11.5 & & & -5.2 & 40.0 & 3.5 \\
\hline 1901 & 3.5 & 3.9 & & & -5.9 & 35.6 & 2.3 \\
\hline 1902 & -5.8 & -13.6 & 4.0 & -50.0 & -5.1 & 44.3 & 21.1 \\
\hline Ave & 6.2 & 6.2 & 4.8 & -5.6 & -4.9 & 37.3 & 2.0 \\
\hline
\end{tabular}

Sources: as Table 1

Notes:

col (1) = Return on Capital Employed (Profits before interest and tax to Capital Employed

$\mathrm{col}(2)=$ Return on Equity (Net profit less preference dividends to Equity)

$\mathrm{col}(3)=$ Return to Ordinary shareholders (Dividends to Ordinary shareholders)

$\mathrm{col}(4)=$ Return on Preference (Dividends to Preference shareholders)

col $(5)=$ Return on Debentures (Interest to Debenture holders)

col (6) = Preference \& Debentures to Capital Employed

$\mathrm{col}(7)=$ Depreciation to fixed assets 


\section{Archival sources}

Barrow Records Office, BD HJ 163/3/1, Draft deed of agreement Haematite Steel Co Ltd and Schneider and Hannay, 1864.

Guildhall Library, London, annual reports filed with Stock Exchange; Barrow Haematite Steel Co Ltd 1883-1964.

National Archives (NA), BT31/1126c/44942-44944, Company files Barrow Haematite Iron and Steel Co Ltd.

National Archives of Scotland, Buccleuch papers; GD 224/144/5 Printed papers, mainly annual reports of the Barrow Haematite Steel Co Ltd, 1865-82.

Parliamentary Archives, House of Lords, London, Barrow Haematite Steel Co. Ltd Act 1902; An Act to provide for the settlement of questions which have arisen between the preference shareholders and ordinary shareholders in Barrow Haematite Steel Co Ltd and for other purposes, Local Act 2 Edward VII c.ccxxxvii HL/PO/PB/1/1902/2E7n266 1902.

\section{References}

Abe, E., 1996. The technological strategy of a leading iron and steel firm, Bolckow Vaughan and Co. Ltd: late Victorian industrialists did fail. Business History, 38 (1), 45-76.

Ammonia Soda Company v Chamberlain (1918) 1 Ch. 266

Andews, P. W. S. and Brunner, E., 1951. Capital Development in Steel: a Study of United Steel Cos Ltd. London: Blackwell.

Ardern, D. and Aiken, M., 2005. An accounting history of capital maintenance: legal precedents for managerial autonomy in the UK. Accounting Historians Journal, 32 (1), 23-60

Armour, J., 2000. Share capital and creditor protection: efficient rules for a modern Company Law. Modern Law Review, 63 (3), 355-378.

Bannatyne v Direct Spanish Telegraph Company, (1886) 34 Ch. D. 287.

re Barrow Haematite Steel Company, (1888) L.R. 39 Ch. D. 582.

re Barrow Haematite Steel Company, (1900) 2 Ch. 846.

re Barrow Haematite Steel Company, (1901) 2 Ch. 746.

Birch, A., 1967. The Economic History of the British Iron and Steel Industry, 1784-1879. London: Cass.

Blair, M. M. 2003a. Locking in capital: what corporate law achieved for business organizers in the nineteenth century. UCLA Law Review, 51 (2), 387-455.

Blair, M. M. 2003b. Why markets chose the corporate form: entity status and the separation of asset ownership from control. Georgetown Law and Economics Research Paper 429300.

Bond v Barrow Haematite Steel Company, (1902) 1 Ch. 353

Bryer, R. A., 1998. The laws of accounting in late nineteenth century Britain. Accounting History, 3 (1), 55-94.

Bryer, R. A., 2000. The history of accounting and the transition to capitalism in England. Part one: theory. Accounting, Organizations and Society, 25 (2), 131-62. 
Cannadine, D., 1977. The Landowner as Millionaire: The Finances of the Dukes of Devonshire, c. 1880-1926. Agriculture History Review, 25 (2), 77-97.

Carr, J. C. and Taplin, W., 1962. History of the British Steel Industry. Cambridge. Mass: Harvard University Press.

Chiapello, E., 2007. Accounting and the birth of the notion of capitalism. Critical Perspectives on Accounting, 18 (3), 263-96.

Companies Clauses Consolidation Act 1845, (8 \& 9 Vict c 16)

Companies Act 1867 (30 \& 31 Vict c 131)

Companies Act 1877 (40 \& 41 Vict c 26)

Companies Act 1947 (10 \& 11 Geo 6 c 47)

Companies Act 1948 (11 \& 12 Geo 6 c 38)

Companies Act 1981 (c 31)

Companies Act 1985 (c 6)

Companies Act 2006 (c 46)

Cottrell, P. L., 1980. Industrial Finance 1830-1914. London: Methuen.

re Ebbw Vale Steel, Iron, and Coal Company, (1877) 4 Ch. D. 827.

Edwards, J. R., 1980. British capital accounting practices and business finance 1852-1919: an exemplification. Accounting and Business Research, 10, 241-58.

Edwards, J. R., 1989. A History of Financial Accounting. London: Routledge.

Ferran, E., 1999. Company Law and Corporate Finance. Oxford: Oxford University Press.

Floud, R., 1994. Britain, 1860-1914: a survey, in Floud, R and D. McCloskey (eds.) The Economic History of Britain since 1700, Vol 2: 1860-1939 (second ed.), 1-28.

French, E. A., 1977. The evolution of the dividend law of England, in Baxter, W. T. and Davidson, S. (eds). Studies in Accounting, London: Institute of Chartered Accountants in England and Wales. 306-31.

Hicks, J. R., 1948. Value and Capital (Second edition). Oxford: Oxford University Press.

Hope v International Financial Society Ltd, (1877) 46 L. J. Ch. 200.

Inflation Accounting. 1975. Report of the Inflation Accounting Committee (Sandilands Committee), Cmnd. 6225. London: HMSO.

Jefferys, J. B., 1946. The denomination and character of shares, 1855-1885. Economic History Review, 16 (1), 45-55.

Joint Stock Companies Act 1856 (19 \& 20 Vict c 47).

re Kingston Cotton Mills Co. No. 2 (1896) 1 Ch 331.

Lee v Neuchatel Asphalte Company, (1889) 41 Ch. D. 1. 
Limited Liability Act 1855 (18 \& 19 Vict c 133).

Marshall, A., 1890. Principles of Economics, Vol. 1. London: Macmillan.

Marshall, J. D., 1958. Furness and the Industrial Revolution. Barrow: Barrow-in-Furness Library and Museum Committee.

Marx, K., 1978. Capital (Volumes 1 and 2). Harmondsworth, Middlesex: Penguin.

Mason, P., 1932. Profits and surplus available for dividends. Accounting Review, 7 (1), 61-66.

Mayson, S. W., French, D. and Ryan, C., 1996. Company Law (Thirteenth edition). London: Blackstone Press.

McCartney, S. and A. J. Arnold, 2012. Financial capitalism, incorporation and the emergence of financial reporting information. Accounting, Auditing and Accountability Journal, 25 (8), 1290-1316.

McCloskey, D. N., 1970. Did Victorian Britain fail? Economic History Review. 23 (3), 446-459.

Morris, R. D., 1986. Lee v. Neuchatel Asphalte Company (1889) and depreciation accounting: two empirical studies. Accounting and Business Research, 16, 71-81.

Napier, C. J., 2015. The British aristocracy, capital and income. Paper presented at the Eighth Accounting History International Conference, Ballarat, Australia.

Pickering, M. A., 1963. The problem of the preference share. Modern Law Review, 26 (5), 499519.

Pollard, S., 1954. Town planning in the nineteenth century: the beginnings of modern Barrowin-Furness. Transactions of the Lancashire and Cheshire Antiquarian Society, 87-116.

Pollard, S., 1955. Barrow-in-Furness and the Seventh Duke of Devonshire. Economic History Review, VIII (2), 213-21.

Pollard, S. and Marshall, J. D., 1953. Furness Railway and the growth of Barrow. Journal of Transport History, 1 (2), 109-26.

Reid, J. M., 1986. Law and Accounting: pre-1889 British Legal cases. New York: Garland.

Reid, J. M., 1987a. Judicial intervention in accounting behavior: a reevaluation of the nineteenth century experience. Journal of Accounting and Public Policy, 6, 9-34.

Reid, J. M., 1987b. Judicial views on accounting in Britain. Accounting and Business Research, 17, 247-58.

Reid, J. M., 1988. Legal acceptance of accounting principles in Great Britain and the United States. Accounting Historians Journal, 15 (1), 1-27.

Ribstein, L. E., 2005. Should history lock in lock-in? Tulsa Law Review, 41, 523-40.

Roepke, H. G., 1956. Movements of the British Iron and Steel Industry, 1720 to 1951. Urbana: University of Illinois Press.

Rutterford, J., J. Maltby, D. R Green and A. Owens, 2009. Researching shareholding and investment in England and Wales: Approaches, sources and methods. Accounting History, 14 (3), 269-292. 
Toms, J. S., 2010. Calculating profit: a historical perspective on the development of capitalism. Accounting, Organizations and Society, 35 (2), 205-21.

Trevor v Whitworth (1887), 12 App Cas 409, HL.

Verner v General and Commercial Investment Trust (1894) 2 Ch 239.

Yamey, B. S., 1941. Aspects of the law relating to company dividends. Modern Law Review, 4 (4), 273-98. 


\section{Capital reduction case law decisions and the development of the capital maintenance doctrine in late nineteenth century England}

Abstract (19ㅁ4 words)

Incorporation with limited liability enabled companies to 'lock-in' their financial capital' and then invest in the long-term, highly specific investments on which the modern industrial economy would be based. The level of benefit varied from country to country, according to the way that the concept of capital lock-in, or maintenance, was defined in the legal systems concerned.

In the UK, the concept was not well defined in early company legislation and challenges were raised through the courts during the late nineteenth century. Some of these, the 'dividend cases', have been quite widely considered in the literature but direct reductions of share capital, or capital reduction schemes, have received far less attention, even though they raised fundamental issues concerning long-term dividend positions, the accounting treatment of accumulated losses, depreciation and asset values and had important effects on the development of the capital maintenance doctrine and on shareholder class rights.

The purpose of this paper is to question whether this literature adequately captures judicial influences on the development of the capital maintenance doctrine in England during the latter part of the nineteenth century, given the limited attention that has been paid to date to the leading capital reduction cases.

\section{Keywords}

Capital reduction schemes

L

Shareholder class rights

Capital maintenance

Nineteenth century accounting 


\title{
Capital reduction case law decisions and the development of the capital maintenance doctrine in late nineteenth century England
}

\begin{abstract}
1.Introduction
Incorporation with limited liability is a business device that enabled nineteenth century firms to amass large amounts of capital. Blair has recently argued that this was one of their mainkey advantages. Companies had the 'ability to commit capital, once amassed, for extended periods of time' and the 'unique manner in which incorporation permitted organizers to lock-in financial capital' made them highly popular in the nineteenth century (Blair 2003a, p. 387). ${ }^{1}$
\end{abstract}

The arrangement was also beneficial to the economy; once locked-in, capital could more easily be spent on the 'long-term, highly specific investments' on which the modern industrial economy would be based (Blair 2003a, p. 390), although the level of benefit was bound to vary from country to country, according to the way that the concept of capital lock-in, or maintenance, was defined in the legal systems concerned. In the UK, companies could be formed with limited liability by simple registration from 1855 and by the end of the nineteenth century, as accounting practices became more established, statutes and court cases had addressed the question of what the concept of capital maintenance really meant.

Case law was very important to this process, given the reluctance of the legislature to fully define the workings of incorporation -- 'distributable profits', for example, were not defined by legislation until 1980 -- and Ardern and Aiken, in a recent 'accounting history of capital maintenance', saw 'disputes concerned with measurement issues, while relatively few' as 'centred on the recurring debate over the amount of profits available for the purposes of dividend distribution' (Ardern and Aiken 2005, p. 24). French concluded that 'many of the points of potential weakness of the capital maintenance doctrine were explored in litigation' in the period 1862 to 1889 (French 1977, p. 309) while Yamey also argued that 1889 (the date of the decision in Lee $v$ Neuchatel Asphalte Company) was of pivotal importance to the development of the capital maintenance concept in England (Yamey 1941, pp. 274-78).

A substantial literature has considered a wide set of late nineteenth century court cases, 'the dividend cases', and arrived at a number of conclusions. The purpose of this paper is to

1 Ribstein has argued that capital lock-ins were also available through the partnership form and that the lock-in was 'backed by politically influential corporate managers because of its role in underpinning managers power ... over the corporate cash'; 2005, pp. 524, 538. 
question whether this literature adequately captures judicial influences on the development of the capital maintenance doctrine in England during the latter part of the nineteenth century, given the limited attention that has been paid to date to the leading capital reduction cases.

The paper is divided into five sections. The next discusses the capital maintenance concept and identifies the various mechanisms that affect it. A third section examines the early capital reduction cases and the financial and industrial context within which they were presented to the courts in the latter part of the nineteenth century. The most difficult issue that these cases had to consider was the treatment of the existing assets of firms in declining trades with complex shareholder class rights. The leading cases in this difficult area arose out of two major capital reduction schemes at one of the largest steel companies in the world, Barrow Haematite Steel Company Ltd (BHS) and, in the fourth section of this paper, the judicial decisions on these cases are related to an analysis of its financial situation, accounting practices and approach to capital maintenance. ${ }^{2}$ This provides the basis for much of the discussion and conclusions in the final section of the paper.

\section{The capital maintenance concept and the mechanisms that affect it}

The concept of capital lock-in, or maintenance, is central to class rights under company law and to economic and accounting formulations of profit. As Ferran explains, 'at the heart of English company law is the recognition that there is a price to be paid for limited liability in the form of restrictions on the use of the company's capital' (1999, p. 355). ${ }^{3}$ Here 'capital' clearly means ownership monies put into the business. The word 'capital' in this paper also generally refers to ownership inputs, except where indicated otherwise. Owners, as shareholders in a limited company, are able to limit their exposure to the claims for repayment of the creditors of that business by meeting legal requirements to publish financial information about the business and by accepting that the circumstances under which ownership capital can be returned will be circumscribed.

Capital maintenance is also central to the concept of economic income which underpins accounting measurements of profit. Thus, to Hicks, income was the maximum amount that could be consumed during a week, still leaving the consumer 'as well off at the end of the week as he was at the beginning' (1948 p. 172), an approach which can be readily reformulated to fit

2 See re Barrow Haematite Steel Company (1888) L.R. 39 Ch. D. 582; re Barrow Haematite Steel Company (1900) 2 Ch. 846; re Barrow Haematite Steel Company (1901) 2 Ch. 746; Bond v Barrow Haematite Steel Company (1902) $1 \mathrm{Ch}$. 353. The company also obtained an Act of Parliament in 1902 that resolved some of the issues concerned; Barrow Haematite Steel Co. Ltd Act 1902.

3.Here 'capital' clearly means ownership monies put into the business. The word 'capital' in this paper generally refers to ownership inputs, except where indicated otherwise. 
business units. ${ }^{4}$ Under such an approach, the capital (of the owners) has been maintained when the amount of net assets at the end of a period is at least equal to the amount at the beginning of the period, excluding any inflows from or outflows to the owners. This basic identity is, however, more problematic than it sounds as there are many different ways to calculate the 'amount' or value of the net assets at the successive points in time.

Although the principle of capital maintenance is simple, the inherent uncertainties of business trading operations (and of the asset valuation process) mean that the concept cannot be (continually) applied in its literal form. Instead of attempts at the 'preservation intact of the value of the shareholders' contribution of assets to a company - i.e. a rule requiring the maintenance of some net asset value', what emerged instead was a requirement 'merely that capital must not be returned to shareholders' before the business was liquidated. ${ }^{5}$ A priori, this could occur in only two ways; through the redemption or purchase of a company's own shares (with or without financial assistance for the purchase) or through the making of dividend payments (or other distributions) to shareholders beyond the identified amounts of the asset surpluses. In recent years the rules that govern these areas have been more closely defined by legislation but, during the late nineteenth century, a formative period for both company law and accounting practice, the definition of these matters by legislation was quite limited and often had to be extended by decisions of the courts.

The first of these areas, the redemption or purchase of a company's own shares, was not in fact a very important issue at the time, given the clear conclusion of the House of Lords in Trevor $v$ Whitworth in 1887 that the practice was unlawful, even to buy out shareholders whose continued presence in the company was undesirable. Lord Macnaughton doubted whether it was possible to 'suggest anything more dangerous to the welfare of companies and to the security of their creditors than such a doctrine' 6

Without share redemptions, the only way that capital can be returned to the shareholders is by way of a dividend payment in situations where the net value of assets had not been maintained. This could only occur with the permission of the courts, but could arise through

| ${ }^{4}$ See, for example, the Report of the Sandilands Committee on Inflation Accounting (1975). It has been argued that a distinctive quality of capitalism is its reasoning in terms of return on capital (profit divided by capital); see Chiapello 2007; Bryer 2000; also Toms 2010.

5 This was clearly expressed in court cases in 1882 and 1887 , although for practical purposes, the common law principle has been surpassed by the statutory rules introduced in 1980; Armour 2000, p. 365. See also the Companies Acts of 1947-48, 1985 (Parts V and VIII) and 2006 (Parts 17, 18 and 23). $\mid 6$ Lord Macnaughton doubted whether it was possible to 'suggest anything more dangerous to the welfare of companies and to the security of their creditors than such a doctrine'; See (1887), 12 App Cas 409, HL. The issuing of redeemable preference shares became possible under the Companies Acts 1947-48, an arrangement extended to ordinary shares by the Companies Act 1981. 
7 Early case law indicated that the resources invested in corporations 'no longer belonged to the shareholders but, rather, remained the property of the corporation unless and until paid out in the form of dividends'; Blair 2003b, p. 18. See Hope $v$ International Financial Society Ltd, (1877) 46 L. J. Ch. 200 regarding the general principle of capital reductions under court supervision. The 1985 Companies Act, s. 142 did later require that a shareholders meeting be called when a company's net assets fell below one half of its called-up share capital.

8 Since October 2008, under the Companies Act 2006 , new procedures are available in situations where capital may have been lost that enable private companies to put forward solvency statements signed by directors instead of seeking the approval of the courts. As Edwards points out, however, solvency tests may work satisfactorily in the short-term but fail to maintain the capital of the business in the long-term;

two distinct mechanisms; firstly if it was agreed that certain losses did not need to be recognised or, having been recognised, could still be ignored for the purpose of calculating the dividend fund (i.e. the maximum possible dividend) or, secondly, if it was agreed that certain losses could be deducted from share capital (or perhaps held as a negative reserve on the balance sheet) rather than charged to profit and loss. The first mechanism led to cases (the 'dividend cases'), that sought the court's view on the legitimacy of immediate dividend payments. The second asked the courts to accept specified reductions in net asset values as permanent and to reduce the share capital part of the ownership claim on the business, rather than charge the losses to profit and loss. This would mean that dividends might the sooner be paid out of any future surpluses, without the encumbrance of accumulated losses on the net assets concerned. Early case law indicated that the resources invested in corporations 'no longer belonged to the shareholders but, rather, remained the property of the corporation unless and until paid out in the form of dividends'. ${ }^{7}$

It will be argued in this paper that, even if the mechanisms were distinct, the main issues that the courts considered in the capital reduction cases were similar to and thus overlapped those raised in the dividend cases. Arguably, however, the effects of the capital reduction cases on the capital maintenance doctrine were the greater, given the direct and wide-ranging questions they raised on asset valuation issues.

The idea of capital maintenance had been inherited from the eighteenth century charter corporations' and reinforced by section 121 of the Companies Clauses Consolidation Act, 1845. Effectively, it 'opposed the notion that limited companies may cancel paid up share capital which was no longer represented by assets', although the Companies Act, 1867 did 'introduce weaknesses' into the doctrine by allowing (under sections 9-14) companies to cancel or reduce their capital, surplus to their requirements, if the consent of the court was obtained and after any creditor objections had been heard (French 1977, pp. 306-07, 311-12). ${ }^{8}$

\section{Formatted: Font: $10 \mathrm{pt}$}

Formatted: Font: Bookman Old Style, 9 pt

Formatted: Font: Bookman Old Style, 9 pt 
It was quite common for the statutes and charters of early companies to state that their dividends could not be paid out of capital or that they were only payable out of profits and it was then for the directors to decide whether a dividend could be paid, although challenges | could be mounted through the courts (see McCartney and Arnold 2012). At first the two phrases 'could not be paid out of capital' and 'only payable out of profits' may have been viewed as synonyms, although the differences between them became important later in the latter part of the nineteenth century (see below).

The courts generally expected the directors to 'decide whether a company could afford to pay a dividend' but they could intervene as, for example, where the profits were inadequate (e.g. when a debt was known to be bad). Flitcroft's case in 1882 established 'beyond doubt the directors' obligation to ... maintain capital intact', although it did not establish any general rule for asset valuation (Edwards 1989, pp. 177-84). The cases cover a wide range of expenses and circumstances 'concerned with establishing whether profit had been properly measured, principally for the purpose of discovering whether a legitimate dividend had been paid'. ${ }^{9}$

The most important case was probably Lee $v$ Neuchatel Asphalte Company (1889), in which it was decided that depreciation (at least in the case of a quarry working) did not have to be charged when calculating distributable profit and that 'the quarry might be valued at original cost for the purpose of deciding whether capital had been maintained intact'. Yamey felt that 'a single unifying idea' (the disapproval of the Legislature of 'any dividend payment which would have left the company with a sum of assets less, in value, than its nominal paid-up capital') had run through the decisions in previous cases and that the Lee decision 'destroyed the existing capital maintenance' theory of the dividend fund in one fell stroke' by approving the 'practice of ignoring declines in the value of a company's property' (Yamey 1941, pp. 274-78). ${ }^{10}$ Edwards, on the other hand, thought the cases, including Lee, helped to 'clarify profit measurement procedures at a time when there were no statutory regulations or generally accepted accounting procedures in the modern sense of the term' (Edwards 1989, p. 177).

\footnotetext{
9 Expenses generally caused greater problems although profit measurement issues could also arise over receipts. See Yamey 1941; French 1977; Reid 1986, 1987a, 1987b, 1988; Morris 1986; Edwards 1989, pp. 177-84.

10 See also Verner (1894) in which Lindley, L J, made clear the new rule; assets were to be divided into two classes, fixed and circulating, and only declines in the value of the latter needed to be allowed for in calculating the size of the dividend fund. The fact that depreciation on fixed assets could be ignored was confirmed in re Kingston Cotton Mills Co. No. 2 (1896) 1 Ch 331. Later, Ammonia Soda Company $v$ Chamberlain (1918) $1 \mathrm{Ch}$. 266 took decisions on unrealized increases in the value of property; Yamey 1941 , pp. $280-84$.
} 
The case was also important as Lindley, $\mathrm{L} \mathrm{J}$ indicated that 'profit measurement was a matter for businessmen and not a proper subject for an Act of Parliament'; identified his concerns that a strict interpretation of the capital maintenance doctrine might mean that funds would be 'arbitrarily locked into business entities' and thereby 'prohibit honest business and paralyse the trade of the country'; and that capital should be understood as the assets rather than the ownership inputs and then restricted to its circulating and not fixed elements. ${ }^{11}$

\section{The main capital reduction cases and their financial and industrial context}

The last quarter of the nineteenth century was a period in which trading conditions were quite difficult in some industries, particularly in iron and steel, the "first manufacturing industry to require capital expenditure on a sufficient scale to stimulate the widespread adoption of joint stock company status' (Edwards 1980, p. 243). There were considerable technological changes in iron and steel in the second half of the nineteenth century that encouraged investment but also brought long periods of 'uncertainty, pessimism and ... stagnation'; in 1875, Britain produced almost 40 percent of the world's steel but by 1896 its output had fallen to 22.5 percent. ${ }^{12}$ This meant that, in an important industry that had invested heavily in long-term, highly specific assets, the directors of many companies had good reason to believe that a good deal of the shareholders' money was tied up in assets with poor commercial prospects.

During the same period of time, the capital structure of companies in a wide range of industries had changed considerably; although 'few companies during the 1860s and early 1870 s made use of loan capital', by 1895 , preference shares represented $22.5 \%$ and debentures $40.6 \%$ of aggregate paid-up capital. ${ }^{13}$ Preference shares (which were permanent not redeemable until 1948) were likely to have preferential rights concerning dividends (and perhaps cumulative rights thereto) and possibly as far as repayment of capital was concerned. Debentures would carry a defined right to interest payments, whether or not profits had been earned (as would loans from banks and other parties providing temporary finance). These developments meant that capital maintenance would no longer have to consider merely the | competing rights of ordinary shareholders and trade creditors but would in many cases have to also address more complex sets of financial entitlements and claims on the business.

By 1876, the value of the assets of the Ebbw Vale Steel, Iron and Coal Company Ltd, formed

11 Ardern and Aiken 2005, p. 48; French, 1977, p. 315; Edwards 1989, p. 180.

12 The successive Gilchrist-Thomas, acid steel, Siemens and basic steel processes; see McCloskey $19 \overline{7} 0$, p. 448; Floud 1994, pp. 3-4, 15; Birch 1967, pp. 353-86; Roepke 1956, pp. 56-61; Carr and Taplin 1962, pp. 94-97, 123-28; Andrews and Brunner 1951; Abe 1996.

13 See Rutterford 2009; Cottrell 1980, p. 86. By 1915, these proportions would be $30.1 \%$ and $40.7 \%$ respectively: Cottrell 1980, p. 164 ; see also Jefferys 1946 .

Formatted: Font: Bookman Old Style, 9 pt Formatted: Normal (Web), Pattern: Clear (White)

Formatted: Not Highlight 
eight years earlier, had been eroded by a 'great fall ... in the value of iron and coal' and the board sought to write down their ordinary shares (the only class of share capital) by about a third. The court ruled that (with regret) they were not able to do this, as the proposal was 'not an actual reduction, because the capital has (already) been lost. It is merely acknowledging that to be lost which is lost'. Instead, Jessel, M. R. said, the Companies Act 1867 allowed only actual reductions of capital, such as a cancellation of the obligation of the shareholders for further calls on their shares (e.g. in a situation in which the company no longer needed such a large nominal share capital; re Ebbw Vale Steel, Iron, and Coal Company, 1877).

The legal position was changed by a small Companies Act passed later that same year. Capital reductions were now possible under two circumstances; where a reduction of capital could prejudice the creditors (e.g. by lessening the liability of shareholders for unpaid capital, in which case the creditors would have a right of objection) and those where it would not, including instances where 'the assets representing the paid up capital had been lost' (French 1977, p. 312). The new rules thus provided an amended basis for determining a balance of rights of shareholders and creditors, although they did not fully address situations involving different classes of shareholders or where the loss of asset value might be less obvious.

The first signs of the difficulties of accommodating preference shares, in the late nineteenth century, to a capital maintenance doctrine shaped by the more fundamental differences between creditors and ordinary shareholders emerged in 1886, in a case in which the loss of asset value could not have been more obvious. (Bannatyne v Direct Spanish Telegraph Company, 1886) ${ }^{14}$ The asset concerned was not, in a physical sense, 'lost'. The company's original cable between Cornwall and Bilbao began to show signs of failure in 1882 and broke down in 1884 and the company decided to lay down a new cable between those places (with money from an issue of debentures) rather than 'attempt to restore the original cable'; Bannatyne v Direct Spanish Telegraph Company, 1886. The breaching of one of the company's two submarine cables materially reduced their assets, such that they could not properly pay dividends until they had either accumulated enough money to replace the damaged cable, or had reduced their capital so as to bring their nominal capital into line with their surviving assets. The courts were not opposed to the principle of writing down both the assets and the totality of the share capital, but paid careful attention to the division of the write-down as between the ordinary shares and cumulative preference shares (that were preferential as to

14 The asset concerned was not, in fact, 'lost'. The company's original cable between Cornwall and Bilbao began to show signs of failure in 1882 and broke down in 1884 and the company decided to lay down $a$ new cable between those places (with money from an issue of debentures) rather than 'attempt to restore the original cable'. Bannatyne v Direct Spanish Telegraph Company (1886). 
dividends but not to capital repayment).

On its formation in 1864, the company had established general powers to reduce their issued capital and the directors' preferred course of action was to halve the share capital, ordinary and preference alike. Some preference shareholders took out an injunction and Bacon, ViceChancellor of the Court of Chancery, upheld their objections, although the grounds he chose seem curious. He appeared to view, and certainly described, the preference shareholders as 'creditors' and their potential dividends as 'interest' and felt that accepting the right of directors to contract out of the agreement to pay the full amount of the preference dividends would be a way of 'cheating preference shareholders for the benefit of ordinary shareholders', that could invite other 'contrivances'. ${ }^{15}$ Bacon effectively asserted a distinction between all prior claims (including those of preference shareholders) on the one hand and the residual claims of the ordinary shareholders on the other; although preference shareholders are not creditors in the normal sense of the term, their entitlement to both dividends and repayment of capital is essentially circumscribed, such that any reduction of their defined capital would reduce their rights to both capital and dividends. The 'sacrifice' made by ordinary shareholders in capital reductions, on the other hand, was somewhat notional; as the holders of the residual claim, they stood to receive the entire surplus after all previous claims had been settled, both as regards revenues and capital. ${ }^{16}$

At appeal in November, 1886, the company claimed the preference shareholders were quasi partners, who should 'take their share of the loss of capital' and had no right 'at all times and under all circumstances [to] have $\$ 6000$ a year'; instead their entitlement was to 10 per cent. on their share capital, as defined by the company. Lord Justice Cotton accepted this argument, did not find it problematic that the preference capital had been provided before the passing of the Companies Act 1877 (since the company's powers to reduce capital did not specifically exclude preference capital), saw the honesty of the directors proposed scheme as both evident and centrally important and accordingly supported the company's appeal and, therefore, their proposed capital reduction scheme.

15 Interest is not an apt word to express the return to which a shareholder is entitled in respect of shares paid up in due course and not by way of advance. Interest is compensation for delay in payment and is not accurately applied to the share of profits of trading; Mr Justice Farwell, Bond v Barrow Haematite Steel Company, (1902).

16 See Mayson, French and Ryan 1996, p. 153; Ferran 1999, pp. 323-24; Pickering 1963. 


\title{
4. The treatment of the existing assets of firms in declining trades with complex shareholder class rights
}

\begin{abstract}
The circumstances of the Direct Spanish Telegraph Company were quite-unusual__in that The loss of utility of the asset was unambiguous and rapid and arose from the physical deterioration of the asset concerned, with immediate and substantial effects upon the company's earning power. a major part of their assets had effectively been lost. Situations in which assets continued to exist in good physically condition-to exist but were thought to have suffered a loss of utility, whether due to technological obsolescence or to changes in market conditions, were both commonplace and would raise issues that would be more difficult to resolve.
\end{abstract}

The judicial decisions in this difficult area took place in four cases concerning two major capital reduction schemes of Barrow Haematite Steel Company Ltd (BHS) in 1888 and 18991902. The company also obtained a private Act of Parliament after the court cases had been heard. BHS had been formed in 1864 by the Seventh Duke of Devonshire and his business associates, as one of a number of interlocking business ventures in Barrow-in-Furness. ${ }^{17}$ The Duke's dividend income rose from less than $£ 20,000$ in 1866 to more than $£ 150,000$ in 1874, when he had the largest income of any aristocrat in the UK, but fell back to below $£ 20,000$ again in 1884 , when the Devonshire family held more than one-third of the share capital. 18 When early trial conversions of the local ores into Bessemer steel turned out 'most satisfactorily' (Chairman's comments to $1^{\text {st }}$ AGM of BHS 29 March 1865; National Archives of Scotland, Buccleuch papers, GD 224/144/5), a new steelworks was built on the waterfront at Barrow and its operations integrated with the existing ironworks. This produced large amounts of Bessemer steel, much of it to provide rails for the British, American and Canadian markets. ${ }^{19}$

The judicial decisions on capital maintenance were essentially judgments on the company's financial position and accounting practices and these are discussed below. In order to put the discussions in context, a summary of the company's main balance sheet items for the periods

17 It was registered as the Barrow Haematite Iron and Steel Co Ltd, although it generally traded as Barrow Haematite Steel Co Ltd; NAPRO, BT31/1126c/44942-44944, BHS company papers. The development of these businesses was behind the spectacular growth of Barrow between 1845 and 1881 ; see Cannadine 1977; Pollard 1954, 1955; Pollard and Marshall 1953; Marshall 1958.

18 Cannadine 1977, pp. 94-96; Pollard 1955, p. 218. The Duke also received royalty payments on a deposit of more than eight million tons of best quality haematite ore that was found on his land in $185 \overline{1}$ the second largest ever find in the UK, and was used extensively by BHS; Marshall 1958, pp. 202-03. 19 The main iron ore deposit they owned contained more than eight million tons of best quality haematite ore; Barrow Records Office, BD HJ 163/3/1, Draft deed of agreement Barrow Haematite Steel Company Ltd (BHS) and Schneider and Hannay, 1864; 1st AGM of BHS, 29 March 1865; National Archives of Scotland, Buccleuch papers, GD 224/144/5; Marshall 1958, pp. 251-57, 343; Carr and Taplin 1962, p. 29.

\begin{tabular}{l} 
Formatted: Font: Bookman Old Style, 9 pt \\
Formatted: Font: $9 \mathrm{pt}$ \\
Formatted: Font: $9 \mathrm{pt}$ \\
Formatted: Font: $9 \mathrm{pt}$ \\
Formatted: Indented para wide $\mathrm{m}$ \\
Formatted: Font: $9 \mathrm{pt}$ \\
Formatted: Font: Bookman Old Style, $9 \mathrm{pt}$ \\
\hline
\end{tabular}


1864 to 1873,1874 to 1888 and 1889 to 1902 are shown in Table 1 , together with profit and | loss items for the same periods of time in Table 2 and selectedkey financial ratios in Table 3.20

\section{TABLES 1-3 TO GO HERE}

The company's strategy was at first hugely successful. By 1873 it was the largest steel company in Britain, if not the world and in 1871-3the three previous years its total capital had earned $22.3 \%$ on average and its ordinary shares 28\%. ${ }^{21}$ Enormous dividends (see Table 2 col. 7 and Table 3 col. 3) had brought spectacular recovery to the Duke of Devonshire's previously stretched financial affairs. This persuaded him to plough even more money back into the business, ${ }^{22}$ just as the boom was about to collapse. There followed a 'long period of uncertainty, pessimism and ... stagnation' in the iron and steel industry, with particular problems for Bessemer steel producers. ${ }^{23}$

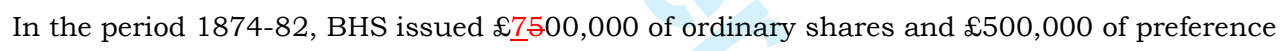
shares (some at $8 \%$ and the remainder at $6 \%$ ) to support a major programme of expansion and diversification. By 1887 they were in real difficulty; returns on capital in the three previous years were down to $1.1 \%,{ }^{24}$ no dividends had been paid despite very low charges for depreciation and there were no retained profits, or reserves (see Table 2 cols. 2 and 7; Table 1 cols. 2 and 3).

BHS’s first capital reduction was in 1888. The company had fixed assets of $£ 2.2 \mathrm{~m}$, but a diversification into coal mining had been both expensive (costing $£ 603,000,27.4 \%$ of total fixed assets) and ill-judged and in 1888 the company's Annual Report announced the abandonment of their colliery in South Wales. It also stated that $£ 509,425$ was to be written off the assets. ${ }^{25}$ Losses are recognised when a reduced monetary value is placed on a particular asset. Normal losses on the operations of the business would then be charged against profits but the

20 The main data was obtained from: Barrow Records Office, BD HJ 163/3/1, Draft deed of agreement between BHS and Schneider and Hannay and the National ArchivesPublic Records Office, BT31/1126c/44942-44944, Company files BHS for 1864; the National Archives of Scotland, Buccleuch papers; GD 224/144/5 BHS annual reports for 1865-82 and the Guildhall Library, London, annual. reports filed with Stock Exchange-annual reports, BHS for 1883-1902.

21 Pollard 1955, p. 215; Pollard and Marshall 1953, p. 122; Carr and Taplin 1962, p. 84 . See Table 3 col. 1 1871-73 ((19.3+20.4+27.3)/3); Table 3 col. 2 1871-73 ((24.0+25.9+34.2)/3).

22 Cannadine 1977, pp. 84-85, 94-96; Pollard 1954, 1955.

23 Birch 1967, p. 353; see also Pollard 1955, p. 216; Carr and Taplin 1962, pp. 95, 123-28.

24 See Table 3 col. 1 1885-87 ((0.9+1.2+1.3)/3).

25 The asset write-off of $£ 509,425$ came under six heads: $£ 220,460$ for the 'depreciation in value' on the Yorkshire colliery (on which $£ 370,460$ had been spent); $£ 190,000$ on its South Wales colliery ( 1197,452 spent); $£ 33,000$ on the Lancashire colliery ( 34,815 spent); $£ 5,000$ reduction in coal royalties received in advance; £27,291 off general working stock; £33,674 off debtors; Annual report to 24th AGM of BHS, 14

March 1888, Guildhall Library, annual reports filed with Stock Exchange-annual reports.

Formatted: Font: 9 pt

Formatted: Font: Bookman Old Style, 9 pt 
26 Annual report to 24th AGM of BHS p. 4, 14 March 1888, Guildhall Library, annual reports filed with Stock Exchange-annual reports. In fact, in the earlier case, the articles of the company contained a power to reduce the capital at the point in time when the preference shares were issued and could therefore be seen as part of an agreed bargain. At BHS, the capital reduction was based upon a general entitlement in section 9 of the Companies Act 1867 and the subsequent amendment of the company's articles by special resolution in 1885, on which the preference shareholders could not vote; see re Barrow Haematite Steel Company, Chancery Division, 1888. The passing of the resolution in 1885 was itself caused directly by the situation at the collieries; the annual report to the members meeting in March indicated that counsels advice was being taken as to 'how best to deal with the capital loss' concerned; Annual report to 21 st AGM of BHS pp. 3-4, 16 March 1885, Guildhall Library, annual reports filed with Stock Exchange_annual reports.

27 They also argued that the lack of available profits was partly due to imprudent ordinary dividend company viewed these losses as more strategic in nature. They did not want to charge them against profits as they were so large that they would probably block dividends for an indefinite period'; instead the company would seek the court's approval for a direct reduction in the share capital.

The directors' advised the ordinary shareholders that, following the Direct Spanish Telegraph Company decision (see above), any capital reduction should fall on preference as well as ordinary shareholders and that 'no legal distinction could be drawn' between the position of the preference shareholders in the two cases, although there were grounds to doubt this advice. ${ }^{26}$ The preference shareholders raised several objections, two of which went to the heart of the capital maintenance issue. ${ }^{27}$ Firstly, that there had been 'no corresponding revaluation of such portions of the property of the company as have increased in value' and secondly that, since 'for some years nothing was written off for depreciation of assets ... the effect of the proposed reduction will be to make the preference shareholders contribute to the depreciation, while the ordinary shareholders have had all the benefit of the company's prosperity' (re Barrow Haematite Steel Company, 1888). There was no legal requirement at this time for depreciation to be charged against profits and individual businessmen were able to retain significant discretion over the ways in which the profits of their business were defined and to vary the accounting practices, notably regarding fixed assets, to the changing circumstances of their trade (Edwards 1980, p. 242). BHS was no different. During the period of high profits from 1866-73 it charged depreciation averaging $£ 33,600$ a year but in $1874-78$ it charged nothing. Thereafter its depreciation charges were generally small (see Table 2 col. 2). Over the period 1866-84 its depreciation charges averaged $£ 28,200$ p.a. (see Table 2 col. 2) on fixed assets averaging $£ 1,417,7,00$ (see Table $1 \mathrm{col} .7$ ), at an average annual rate of $2.0 \%$. Clearly, these charges did not recognise the wearing out of the assets concerned, particularly in an industry in which there was considerable technological change. The financial statements did not payments in 1873-83 totalling $£ 1,043,000$ (see Table 2, col. 7; although none had been had been paid in 1884-88, when the arrears of preference dividends had reached 1124,000 ) and that the ordinary shares had been increased by $£ 500,000$ through bonus issues out of profits in 1867-74, without which there would be 'no necessity for the reduction of capital' (see Table 2, col. 8). 


\section{indicate any active policy of valuing the assets according to expert trade valuations, except in} times of crisis. ${ }^{28}$

Mr. Justice North did not entirely accept the company's claims but he did decide that 'there was nothing unfair or inequitable' in their proposals and that the preference shareholders should therefore take their share of those losses (and thereby accept an immediate reduction in their future entitlement to dividends; re Barrow Haematite Steel Company, 1888). The scheme was considered as a whole and little attention was apparently paid to any accounting issues or to the components of the asset write-off; thus all six write-offs were accepted as capital, not revenue (see above). While the South Wales and Lancashire collieries were abandonments, the Yorkshire colliery was not (and would still be owned and used by BHS in the 1930s). The other three items were all relatively normal adjustments to current assets, including a reduction in the value of stock due to 'improved systems of manufacture' and for a probable bad debt (Annual report to 24th AGM of BHS pp. 3-4, 14 March 1888, Guildhall Library, annual reports filed with Stock Exchange-annual reports)! This was a legal decision that could not last.

Capital employed at BHS had been reduced in 1888 to $£ 2.2 \mathrm{~m}$, by writing down both classes of share capital by a quarter, and it remained at approximately that level for the rest of the century, during which period returns on capital employed averaged $3.25 \%$, well below the rate of interest on debt and despite depreciation charges that averaged slightly less than $1 \%$ of fixed asset book values. ${ }^{29}$ In 1899, the directors announced that a further reduction of capital was 'inevitable'; many of the fixed assets had not been written down in the earlier scheme, as they had not 'foreseen that the company would have to contend for some years with a serious depression in the iron and steel trade'. Accordingly they proposed the writingete down of their

28. There was no legal requirement at this time for depreciation to be charged against profits and individual businessmen were able to retain significant discretion over the ways in which the profits of their business were defined and to vary the accounting practices, notably regarding fixed assets, to the changing circumstances of their trade (Edwards 1980, p. 242). BHS was no different. During the period of high profits from 1866-73 it charged depreciation averaging $\$ 34,000$ a year but in 1874-78 it charged nothing. Thereafter its depreciation charges were generally small (see Table 2 col. 2). Over the period 1866-84 its depreciation charges averaged $\$ 19,000$ p.a. (see Table 2 col. 2) on fixed assets averaging $£ 1,529,000$ (see Table $1 \mathrm{col} .7$ ), at an average annual rate of $1.24 \%$. Clearly, these charges would not recognise the wearing out of the assets concerned, particularly in an industry in which there was considerable technological change. The financial statements did not indicate any active policy of valuing the assets according to expert trade valuations, except in times of crisis.

29 The ordinary share capital was reduced by $£ 375,000$ and the preference shares by the remaining $£ 134,425$. Ex post, the preference shareholders came out of the 1888 reductions quite well; in 1888-1899 they received dividends of $£ 330,000$, which greatly reduced the arrears of their dividends, whereas the ordinary shareholders received only two small dividends, each of $2.5 \%$; see Table 2 , cols. 6 - 7 ). The returns on capital employed were from 1889-1899 inclusive; see Table $3 \mathrm{col}$. 1 . The rates of return would of course have been even lower had the capital figures not been reduced in 1888 . The average annual charge for depreciation for $1889-99$ (see Table 2 col. 2) was $£ 17,700$; the average fixed asset book value for the same period was $£ 1,821,000$ (see Table 1 col. 7). 
fixed assets byfrom $£ 1,647,931$ to $£ 883,793$, holding the difference (of $£ 764,138$ ), held in a Depreciation Suspense Account as a separate asset and recommending that all classes of share capital be halved (Letter to BHS shareholders from the directors of 14 November 1899;

| Guildhall Library, annual reports filed with Stock Exchange-annual reports). ${ }^{30}$

Many of the preference shareholders opposed this, lest circumstances should arise under which the company would again make large profits (quoted in letter to BHS shareholders from the directors of 29 March 1900; Guildhall Library, annual reports filed with Stock Exchange annual reports). The situation also differed somewhat from 1888; no equity dividends had been paid since 1892, as the directors would not recommend any 'until the capital reduction proposal were resolved', and retained profits in 1901 were the highest in the company's history, despite depreciation charges in 1900 and 1901 that were the highest for twenty years (see Table 1 cols. 2 and 3 and Table 2 col. 2)!

In court, Mr. Justice Cozens-Hardy explained that the case law in this area had changed in the last twelve years (he referred specifically to Lee $v$ Neuchatel Asphalte Company, 1889 and Verner $v$ General and Commercial Investment Trust, 1894), such that, where part of the fixed capital of a company had been lost, it could still pay dividends out of its current profits. In view of the 'state of the law as now recognised' he saw 'no necessity for a reduction', particularly in the light of the un-appropriated profits and reserves, and did not want to act on the 'balance of speculative expert evidence as to the value of mining property'. He thought the business could still be carried on as it was and felt that reducing the capital would 'in no way affect the business of the company, or benefit the company looked on as a whole'; instead he believed that its effect would be an injustice to the preference shareholders, taking dividends out of the pockets of the preference shareholders and giving them to the ordinary shareholders, in 'derogation of the original bargain they made' (re Barrow Haematite Steel Company, 1900). The judge agreed that the directors had to keep 'true and honest accounts', but thought they could 'honestly and properly prepare a balance-sheet shewing or implying a loss of capital, and at the same time may honestly and properly prepare a loss and profit account shewing a balance available for dividend'. The judge's comment that 'reserves and un-appropriated profit ought to be considered as available assets' also suggests that he was not clear on the differences between the two sides of the balance sheet and, therefore, whether capital meant the

\footnotetext{
30 Of the fixed asset reductions, £214,016 were 'realised losses'; £146,657 on the surrender of some iron ore mines, $£ 28,240$ on blast furnaces that had been pulled down and $£ 39,119$ from the sale of houses and land. The remaining $£ 550,122$ was based on the estimates of 'expert valuers'. The capital consisted of $£ 1,125,000$ in ordinary shares and $£ 28,275$ in $8 \%$ and $£ 375,000$ in $6 \%$ preference shares; annual report to 37th AGM of BHS, 2 April 1901; Guildhall Library, annual reports filed with Stock Exchange_annual reports.
}

Formatted: Font: $10 \mathrm{pt}$ 
ownership inputs or the company's assets, whether fixed or circulating; re Barrow Haematite Steel Company, 1900. ${ }^{31}$

When the case went to appeal, the appeal judges indicated that they were unconvinced that capital had been lost to the extent of more than $£ 764,000$ and that the decision, which they upheld, relied primarily on a view that the proposed reductions would not be fair and equitable as between the preference and the ordinary shareholders (re Barrow Haematite Steel Company, 1901). A year later, these matters came to court again (in Bond $v$ Barrow Haematite Steel Company, 1902) when the preference shareholders sought the payment of their fixed, cumulative preference dividends, on the grounds that the losses arising out of the flooding of mines and miners cottages could be ignored in calculating the dividend fund'.

Mr. Justice Farwell_accepted that BHS had suffered realised losses of capital of £214,016, noted that the case, as put forward by the preference shareholders did not require him to make any distinction between realized and estimated losses and thought it would serve no useful purpose' if he did. What seemed mMore important, following Lindley, was the argument fact that, although in some cases fixed capital might be sunk and lost, without precluding the payment of a dividend, circulating capital must be kept up. Mining was not the main business of the company but was merely there to supply iron ore to the main business; "by way of economy they acquired the leases of the surrendered mines in order to supply themselves with their own ore instead of buying it as required', while the blast furnaces and cottages were merely ancillary such that the money invested in these items could be "properly regarded in this company as circulating capital'. The mines were 'drowned out and the cost of pumping them out was prohibitive. The company, therefore, surrendered the leases, pulled down the blast furnaces, and sold the cottages connected therewith' ${ }^{32}$ (the $£ 214,016$ was the 'realised losses of $£ 146,657$ on the surrender of some iron ore mines, $£ 28,240$ on blast furnaces that had been pulled down and £39,119 from the sale of houses and land). Mr. Justice Farwell noted that the courts had often over-ruled directors who proposed to pay dividends, but he was not aware of 'any case in which the Court has compelled them to pay when they have expressed their opinion that the state of the accounts did not admit of any such payment. In a matter depending on evidence and expert opinion, it would be a very strong measure for the

31. The judge agreed that the directors had to keep 'true and honest accounts', but thought they could shonestly and properly prepare a balance-sheet shewing or implying a loss of capital, and at the same time may honestly and properly prepare a loss and profit account shewing a balance available for dividend'. The judge's comment that 'reserves and un-appropriated profit ought to be considered as available assets' also suggests that he was not clear on the differences between the two sides of the balance sheet and, therefore, whether capital meant the ownership inputs or the company's assets, whether fixed or circulating; re Barrow Haematite Steel Company, 1900.

32 See footnote 30 for details of the various losses, realised and estimated.

Formatted: Font: $10 \mathrm{pt}$

Formatted: Font: Bookman Old Style, 9 pt

Formatted: Font: Bookman Old Style, 9 pt

Formatted: Font: Bookman Old Style, 9 pt

Formatted: Font: Bookman Old Style 
Court to override the directors in such a manner'. Instead, the courts upheld the fundamental right of directors to propose maximum dividends, whether on ordinary or preference shares. ${ }^{33}$

-He also saw important differences between the statutory requirement that "dividends must not 4 be paid out of capital" and a clause often included in company articles that "dividends may only be paid out of profits" and saw nothing in the statutes requiring a company to keep up the value of its capital assets to the level of its nominal capital. ${ }^{34}$ The real question, of whether there were profits available for distribution, was seen as 'difficult' and issues concerning the losses that could 'be properly charged to capital, and what to income, was a matter for businessmen to determine', as there was no single definition of the word "profits" which would fit all cases. ${ }^{35}$

These decisions and comments persuaded the company that its assets could and should be written down, and to seek a substantial writing down of all classes of the share capital but to seek this through a route other than the courts. BHS reached agreement with the preference shareholders on a revised arrangement that would made good the arrears of preference dividends and protect their dividend position in the long-term and was then able to obtain an Act of Parliament later that same year reducing each class of share capital by $40 \% .{ }^{36} \mathrm{By}$ December 1902, the assets had been 'depreciated' by the originally scheduled amount, with a substantial contribution from profit and loss (to make good the reduction in the amount from share capital) and this still left enough distributable profits for a $3 \%$ dividend to the ordinary shareholders, the first such payment for ten years. ${ }^{37}$

\footnotetext{
33 This is still the leading case on the principle that 'no dividend is payable on a company's shares, even on preference shares, unless and until the company has decided to pay one'; Mayson, French and Ryan 1996, pp. 282-83.

34 See also Lindley L.J. in Lee v. Neuchatel Asphalte Co., 1889. BHS's article 96 said 'no dividend shall be payable except out of the profits arising from the business of the company'.

35 Of the two he identified, Professor Marshall's and Lord Justice Lindley's, the first clearly looked to an annual comparison of both fixed and circulating capital. Thus, Marshall said that "when a man is engaged in business, his profits for the year are the excess of his receipts from his business during the year over his outlay for his business; the difference between the value of his stock and plant at the end and at the beginning of the year being taken as part of his receipts or as part of his outlay, according as there has been an increase or decrease of value." 'Stock and plant' clearly includes both fixed and circulating capital. Following Mill, circulating capital, 'fulfils the whole of its office in the production in which it is engaged, by a single use' whereas fixed capital, 'exists in a durable shape and the return to which is spread over a period of corresponding duration"; Marshall 1890, pp. 134, 142. The second, Lindley's, argued that 'fixed capital may be sunk and lost, and yet the excess of current receipts over current payments may be divided', as long as the floating or circulating capital was 'kept up' (Lee $v$. Neuchatel Asphalte Co., 1889; Verner v. General and Commercial Investment Trust, 1894).

36 See Parliamentary Archives, House of Lords, Barrow Haematite Steel Co Ltd Act 1902, pp. 4-5. The Companies Act 1862 (25 \& 26 Vict. c.89, s.162) did give companies the power to purchase their own shares with statutory authorization.

37 The ordinary shares and $6 \%$ preference shares were written down from $£ 7.5$ to $£ 4.5$ and the $8 \%$ preference shares from $£ 75$ to $£ 45$, the capital in total from $£ 1,528,275$ to $£ 916,965$, with the remaining
} $£ 152,828$ (of the $£ 764,138$ reduction in assets) transferred from Profit and Loss. The $6 \%$ preference 


\section{Discussion and conclusions}

This paper starts from Blair's argument that the unique manner in which incorporation permitted organizers to lock-in financial capital' was central to the importance of companies as a business form in the nineteenth century (Blair 2003a, p. 387). This brought substantial economic benefit, since capital could then be readily spent on the 'long-term, highly specific investments' on which the modern industrial economy would be based (Blair 2003a, p. 390). The precise level and pattern of benefit would vary between countries, according to the way that their legal systems defined capital lock-in, or maintenance.

In England, although the formation of limited liability companies by simple registration was available from 1855 , legislation was slow to delineate the precise meaning of capital maintenance -- 'distributable profits', for example, were not defined by legislation until $1980-$ and judicial and other influences were the more important.

A substantial literature has considered a wide range of late nineteenth century 'dividend cases', and their implications for the development of the capital maintenance concept. This paper's intention, as set out in the introduction, is to question whether this literature adequately reflects judicial influences on the development of the capital maintenance doctrine in England during this period of time.

Its conclusion is that they do not. This is not because of any particular inadequacies in these papers - they are typically erudite, interesting and well argued - but because the capital maintenance concept was shaped by both immediate dividend payment issues and by the longer-term dividend implications of capital reduction schemes. The paper's central argument is, therefore, that even excellent analyses of dividend cases will not fully explain the evolution of the capital maintenance concept. In support of this argument, it identifies and discusses the issues that arose in an important set of capital reduction cases heard by the courts in the second half of the nineteenth century. There is no implicit claim that the treatment provided in this paper is comprehensive but it does identify an area for further empirical work and an

shares were to receive a (cumulative) annual dividend of $6 \%$ on their reduced capital, with further dividends to be paid at half the rate of any ordinary dividends. The $8 \%$ preference shareholders were to receive a (cumulative) annual dividend of $13.3 \%$ on their reduced capital to maintain their previous annual dividend amount; annual report to 39th AGM of BHS, 18 March 1903; Guildhall Library, annual reports filed with Stock Exchange-annual reports.

Formatted: Normal, Pattern: Clear

Formatted: Font: English (U.K.)

Formatted: Font: English (U.K.) 
appropriate methodology that can be used, in the hope that this will promote further analysis and debate on the evolution of this important concept.

Ardern and Aiken, in a recent 'accounting history of capital maintenance', which reviews the relevant literature in a comprehensive and scholarly manner, saw 'disputes concerned with measurement issues ... as centred on the recurring debate over the amount of profits available for the purposes of dividend distribution' (Ardern and Aiken 2005, p. 24). A section headed 'Alternative Definitions of Capital Maintenance' identified two broad approaches, the surplus approach (where the profit and loss account was secondary to a comparison of net asset valuations at the start and end of the period) and another, where the profit and loss account 'provides the primary evidence of the availability of profit', in both cases to determine the extent to which dividends could be paid (2005, pp. 28-29). No consideration was given in this or any other section to the effects of capital reduction schemes on the capital maintenance concept.

This paper has addressed the question of whether the existing literature adequately captures judicial influences on the development of the capital maintenance doctrine in England during the latter part of the nineteenth century. During this period, companies in a number of industries experienced economic decline and difficulty and also adopted more complex capital structures

Although the term 'capital maintenance' is so widely used and is in principle so simple, tThe uncertainties of business operations and asset valuation processes meant that the concept could not be applied in any literal way; instead what emerged was a requirement that capital should not be returned to the shareholders before the business was liquidated. The decision of the House of Lords in Trevor $v$ Whitworth in 1887, making the redemption or purchase of a company's own shares illegal, meant that capital could only be returned to the shareholders by dividend payments where the net value of assets had not been maintained. This could arise under two judicial procedures; firstly if the courts agreed that certain losses could be disregarded for the purpose of calculating the dividend fund (i.e. the maximum possible dividend) or, secondly, if they agreed that certain capital losses could be deducted from share capital rather than charged to profit and loss. The first mechanism (the 'dividend cases'), addressed the legitimacy of immediate dividend payments and has been widely discussed, while the second (the 'capital reduction cases') affected the company's ability to pay dividends out of future surpluses, but has received far less attention in the literature to date.

As the names of the two-sets suggest, the dividend cases had a more immediate effect on dividend payments and the capital reduction cases addressed capital maintenance issues more directly and broadly. There were significant overlaps between the two procedures - the judicial 
decisions in Lee v. Neuchatel Asphalte Co. (1889) and Verner v. General and Commercial Investment Trust (1894) in particular were sufficiently important to have major effects on both but some of the issues that the courts considered in the capital reduction cases had important effects on the capital maintenance doctrine and on shareholder class rights. in the dividend cases. The capital reduction cases were considered by the courts during a period in which company law was not closely specified and in which the accounting practices of companies were still quite embryonic. The difficult economic circumstances faced by many companies during the late nineteenth century encouraged the putting forward of capital reduction schemes but the increased importance of preference shares meant that cases often raised two simultaneous problems; a primary one as to whether the asset losses should be charged to capital (i.e. set against share capital) or to revenue (charged to the profit and loss account) and the secondary issue of whether any-losses that were to be treated as capital, should be borne by the ordinary shareholders alone or by the preference shareholders as well. The first issue raised directly the capital maintenance problem and the second raised further issues of equity and fairness, since the rights of-ordinary and preference shareholders had differing rights as to

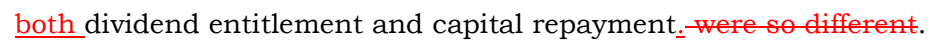

The position of the courts was difficult. The priority of protecting creditors was always recognized, although, as Edwards points out, even if solvency tests work satisfactorily in the short-term they will not maintain the capital of the business in the long-term (Edwards 1989, p. 182. See also Mason 1932, pp. 64-65). There was a clear perception, during difficult times in many industries, that if capital were maintained 'at all costs' the likely outcome would be to 'paralyze the trade of the country' (see Lindley's remarks in Verner (1894); also Ardern and Aiken 2005, pp. 42-47) but the successive issues that arose in the capital reduction cases were not handled consistently or well.

It is quite apparent that 'capital' initially meant shareholders monies, since the applications to * the courts were not for the right to write down asset values; depreciating assets was of course not a requirement at the time but was still something that companies were entitled to do without specific consent. In 1876, although the value of the assets of the Ebbw Vale Steel, Iron and Coal Company Ltd had apparently fallen, the court would not sanction a cut in the share capital as the proposal was 'not an actual reduction, because the capital has (already) been lost. It is merely acknowledging that to be lost which is lost'. Instead, the courts could only allow actual reductions of capital, which they indicated could include a cancellation of the obligation of the shareholders for further calls on their shares (re Ebbw Vale Steel, Iron, and Coal Company, 1877). A The-Companies Act later that year 1877then allowed paid up share capital to be reduced where the assets representing it had been lost but subsequent judicial (1) 
8 decisions extended this considerably to circumstances under which the assets continued to exist, and thus werehad not been 'lost', although theybut might have lost value.

The first signs of the difficulties of fitting preference shares to a capital maintenance doctrine shaped by more fundamental differences between creditors and ordinary shareholders emerged in 1886, in a case in which a substantial loss of asset value was apparent. The directors' intention was to halve the ordinary and preference share capital, but Bacon, Vice-Chancellor of the Court of Chancery, upheld an injunction against this, effectively asserting a distinction between all prior claims (including those of preference shareholders) on the one hand and the residual claims (both for dividends and capital repayment) of the ordinary shareholders on the other. Lord Justice Cotton over-ruled this in November, 1886, seeing the preference shareholders position as more akin to that of the ordinary shareholders than to the creditors.

When the first BHS capital reduction scheme was heard, At times, the courts also-seemed more concerned with treat the more pressing but essentially secondary issue of fairness as between classes of shareholders_as if it were more important than the primary issue of whether the losses of asset value should be directly charged against share capital or not. This matters because the essential condition of trade is that changes in asset value take place all the time, whether recognizable on the basis of individual transactions (e.g. the cost of acquired goods that had been re-sold) or as part of a gradual process (the wear and tear of a machine). Mr. Justice North accepted all six proposed asset write-offs as capital, not revenue, even though three were relatively normal adjustments to current assets and a fourth was merely the unexpected cost of sinking a colliery in Yorkshire that BHS would use until the 1930s. He saw 'nothing unfair or inequitable' in their proposals and thought the preference shareholders capital should take its share of those losses (see above and Table 1, cols. 1, 4, 7-8).

In 1900, the serial inconsistency of the judiciary in the capital reduction cases would be taken a good deal further, following the decisions in Lee $v$ Neuchatel Asphalte Company (1889) and Vernerv General and Commercial Investment Trust (1894). Mr. Justice Cozens-Hardy now clearly saw capital as being on what can be called the 'other (assets) side of the balance sheet', since the key distinction was now (following Lindley) apparently between fixed and circulating capital. He also refused to accept the company's capital reduction proposal as warranted, and was concerned that it would be an injustice to the preference shareholders, taking dividends out of the pockets of the preference shareholders and giving them to the ordinary shareholders, in 'derogation of the original bargain they made'. ${ }^{38}$

| 38 . The judge's further comment that 'reserves and un-appropriated profit ought to be considered as
Formatted: No widow/orphan control, Don't hyphenate, Don't adjust space between Latin and Asian text, Don't adjust space between Asian text and numbers

Formatted: Normal, No widow/orphan control Don't hyphenate, Don't adjust space between Latin and Asian text, Don't adjust space between Asian text and numbers

Formatted: Font: Bookman Old Style, 9 pt

Formatted: Normal, No widow/orphan control, Don't hyphenate, Don't adjust space between Latin and Asian text, Don't adjust space between Asian text and numbers

Formatted: Font: 9 pt

Formatted: Font: 9 pt 
This prioritization of court attention meant that in 1888 (in re Barrow Haematite Steel Company) the following losses were all accepted as capital in nature: reducing the expenditures to disposal value at collieries in South Wales (from $\$ 197,452$ to $\$ 7,452$ ) and Lancashire $(£ 34,815$ to $£ 1,815)$ that the company had decided to abandon; a reduction in expenditures on the Yorkshire colliery $(£ 370,460$ to $£ 150,000)$ that would give useful service to the company for another 45 years; reductions in anticipated coal royalties $(\$ 5,000)$, in general worlking stock $(£ 27,291)$ and in debtors $\left(£ 33,674\right.$; Annual report to $24^{\text {th }}$ AGM of BHS, 14 March 1888 , Guildhall Library, Stock Exchange annual reports).

The decision in the Lee case, to re-define capital in terms of asset categories (circulating and fixed) rather than shareholder inputs may have sufficed for dividend decisions ${ }^{39}$ but the BHS cases in 1900-01 raised the additional issue of whether there was any meaningful distinction between realised and non-realised reductions in asset value. This was viewed by the judiciary as secondary to the main circulating-fixed distinction but the actual decisions made in the court cases of 1900-02 meant that three categories of fixed asset reductions (the realised losses on surrendered iron ore mines $(£ 146,657)$, on closed down blast furnaces $(£ 28,240)$ and on sold houses $(£ 39,119)$ ) along with $£ 550,122$ of write-down's in the 'iron ore mines, iron works, steel works, engineers shops and buildings, waterworks, reservoirs, wireworks and land and house property', consistent with 'expert' valuations (letter to the shareholders of Barrow Haematite, 14 November 1899, Guildhall Library, annual reports filed with Stock Exchange annual reports) were all to be treated as revenue not capital.

The directors of BHS had determinedeided, when putting forward their capital reduction scheme, that the assets and ownership capital on the company Balance Sheet should be brought into line with business 'realities'. Based on previous judicial decisions they had every expectation of They would have liked to also-being able to reduce their future payments of preference dividends but, given the judicial position that emerged in these cases, they decided to forego thise latter (by negotiating an agreed positionrrangement with the preference shareholders that meuld-maintained the latter's dividend entitlements) and proceed by the unusual mechanism of a Parliamentary Private Act. In their judgment, this had become the | mostre sensible way for businesses with highly specific assets and preference capital to cope

available assets' suggests an even greater degree of confusion; re Barrow Haematite Steel Company, 1900. ${ }^{39}$ As Marx and others have shown, the distinction is actually rather relative and unreliable; fixed capital also 'circulates', even if its circulation time is much longer. This being so, it is not difficult to see depreciation charges as a mechanism to estimate the extent to which the 'fixed' had become 'circulating' and therefore properly chargeable against current revenues. See Marx (1978, Vol. 1, pp 760-61) including the comment that 'political economy since the time of Adam Smith has confusedly mixed up the determining characteristics contained in these categories [variable and constant capital] with the merely formal distinction, arising out of the process of circulation, between fixed and circulating capital' (p. 760). See also Vol. 2 (pp. 237-61), including the argument that the peculiar circulation of fixed capital gives rise to a peculiar turnover. The portion of value that it loses in its natural form by wear and tear circulates as a value portion of the product' (p. 242). See also French 1977, pp. 314-22; Yamey 1941, pp. 280-81; Bryer 1998, for a discussion of the distinction between circulating and fixed assets and Napier (2015) for an explanation of the Lee case as the survival of aristocratic attitudes to capital and income. 
with their capital maintenance problems, that had emerged in England in the late nineteenth century.

The intention of this paper has been to show that no account, however satisfactory, of the nineteenth century 'dividend cases' can reveal the full development of the capital maintenance concept during the same period of time. The capital maintenance issues that were provoked by a series of capital reductions in the same time period may or may not be seen as more important but they were clearly significant, different and developed in a different way.

The paper does not argue that this reflects any particular intention or perspective on the part of the governments of the time, who found it hard to deal with the industrial circumstances of the late nineteenth century, particularly in the iron and steel industry, at a time when the basic notion of capital maintenance was complicated by the emergence of preference shares as an important source of capital. The legislature refused to provide a framework that would satisfactorily reconcile the competing interests in relatively new companies and the judiciary was left, in individual cases, to find a satisfactory way forward. Views may differ on their success in the dividend cases but this paper has shown that an important set of capital reduction schemes were handled in a thoroughly inconsistent, even logically incoherent manner, that can have done nothing to improve resource allocation decisions in the English economy of the time. 
Table 1: Barrow Haematite Balance Sheet items, 1864-1902 (£000)

\begin{tabular}{|c|c|c|c|c|c|c|c|c|c|}
\hline & $\begin{array}{c}\text { (1) } \\
\text { Ordinary } \\
\text { shares }\end{array}$ & $\begin{array}{c}\text { (2) } \\
\text { Retained } \\
\text { profits }\end{array}$ & $\begin{array}{c}\text { (3) } \\
\text { General } \\
\text { reserve }\end{array}$ & $\begin{array}{c}\text { (4) } \\
\text { Pref. } \\
\text { shares }\end{array}$ & $\begin{array}{c}\text { (5) } \\
\text { Debent. }\end{array}$ & $\begin{array}{c}(6) \\
\text { Total } \\
\text { capital }\end{array}$ & $\begin{array}{c}(7) \\
\text { Fixed } \\
\text { assets }\end{array}$ & $\begin{array}{c}\text { (8) } \\
\text { Other } \\
\text { net assets }\end{array}$ & $\begin{array}{c}\text { (9) } \\
\text { Total } \\
\text { assets }\end{array}$ \\
\hline 1864 & 57 & & & & & 57 & 21 & 36 & 57 \\
\hline 1865 & 90 & 4 & & & 51 & 145 & 144 & 1 & 145 \\
\hline 1866 & 500 & 75 & & & 255 & 830 & 684 & 146 & 830 \\
\hline 1867 & 540 & 77 & & & 310 & 927 & 778 & 149 & 927 \\
\hline 1868 & 580 & 79 & & & 312 & 971 & 800 & 171 & 971 \\
\hline 1869 & 620 & 81 & & & 306 & 1007 & 814 & 193 & 1007 \\
\hline 1870 & 660 & 83 & & & 288 & 1031 & 875 & 156 & 1031 \\
\hline 1871 & 700 & 127 & & & 270 & 1097 & 876 & 221 & 1097 \\
\hline 1872 & 700 & 203 & & 38 & 270 & 1211 & 878 & 333 & 1211 \\
\hline 1873 & 800 & 310 & & 38 & 300 & 1448 & 1094 & 354 & 1448 \\
\hline 1874 & 1310 & 82 & & 38 & 543 & 1973 & 1311 & 662 & 1973 \\
\hline 1875 & 1390 & 60 & & 38 & 550 & 2038 & 1554 & 484 & 2038 \\
\hline 1876 & 1462 & 71 & & 284 & 550 & 2367 & 1692 & 675 & 2367 \\
\hline 1877 & 1487 & 54 & & 288 & 550 & 2379 & 1785 & 594 & 2379 \\
\hline 1878 & 1498 & 36 & & 288 & 550 & 2372 & 1899 & 473 & 2372 \\
\hline 1879 & 1500 & 75 & & 405 & 533 & 2513 & 1896 & 617 & 2513 \\
\hline 1880 & 1500 & 88 & & 418 & 540 & 2546 & 1938 & 608 & 2546 \\
\hline 1881 & 1500 & 75 & & 430 & 546 & 2551 & 1904 & 647 & 2551 \\
\hline 1882 & 1500 & 45 & & 538 & 550 & 2633 & 1970 & 663 & 2633 \\
\hline 1883 & 1500 & 7 & & 538 & 550 & 2595 & 2064 & 531 & 2595 \\
\hline 1884 & 1500 & 7 & & 538 & 546 & 2591 & 2124 & 467 & 2591 \\
\hline 1885 & 1500 & 3 & & 538 & 546 & 2587 & 2129 & 458 & 2587 \\
\hline 1886 & 1500 & 1 & & 538 & 653 & 2692 & 2149 & 543 & 2692 \\
\hline 1887 & 1500 & 3 & & 538 & 699 & 2740 & 2189 & 551 & 2740 \\
\hline 1888 & 1125 & 43 & & 403 & 643 & 2214 & 1756 & 458 & 2214 \\
\hline 1889 & 1125 & 79 & & 403 & 550 & 2157 & 1777 & 380 & 2157 \\
\hline 1890 & 1125 & 116 & & 403 & 550 & 2194 & 1794 & 400 & 2194 \\
\hline 1891 & 1125 & 70 & 25 & 403 & 550 & 2173 & 1807 & 366 & 2173 \\
\hline 1892 & 1125 & 18 & 50 & 403 & 550 & 2146 & 1832 & 314 & 2146 \\
\hline 1893 & 1125 & 14 & 25 & 403 & 550 & 2117 & 1837 & 280 & 2117 \\
\hline 1894 & 1125 & -8 & & 403 & 550 & 2070 & 1837 & 233 & 2070 \\
\hline 1895 & 1125 & -13 & & 403 & 550 & 2065 & 1837 & 228 & 2065 \\
\hline 1896 & 1125 & 38 & & 403 & 550 & 2116 & 1837 & 279 & 2116 \\
\hline 1897 & 1125 & 46 & 5 & 403 & 550 & 2129 & 1836 & 293 & 2129 \\
\hline 1898 & 1125 & 56 & 20 & 403 & 550 & 2154 & 1825 & 329 & 2154 \\
\hline 1899 & 1125 & 89 & 40 & 403 & 550 & 2207 & 1816 & 391 & 2207 \\
\hline 1900 & 1125 & 246 & 40 & 403 & 539 & 2353 & 1752 & 601 & 2353 \\
\hline 1901 & 1125 & 301 & 40 & 403 & 406 & 2275 & 1707 & 568 & 2275 \\
\hline 1902 & 675 & 54 & 40 & 242 & 370 & 1381 & 900 & 481 & 1381 \\
\hline Ave & 1085 & 72 & 7 & 292 & 469 & 1924 & 1531 & 393 & 1924 \\
\hline
\end{tabular}

Sources: National Archives, BT31/1126c/44942-44944, Company files BHS for 1864

National Archives of Scotland, Buccleuch papers; GD 224/144/5 BHS annual reports for $1865-82$

Guildhall Library, London, annual reports filed with Stock Exchange, BHS for 1883-1902.

Notes: in col (4) Pref. = Preference 
Table 2: Barrow Haematite Profit and Loss items, 1865-1902 (£000)

\begin{tabular}{|c|c|c|c|c|c|c|c|c|c|c|c|}
\hline & $\begin{array}{c}\text { (1) } \\
\text { Trading } \\
\text { profit } \\
\end{array}$ & Deprec. & $\begin{array}{c}\text { (3) } \\
\text { Debent. } \\
\text { interest }\end{array}$ & $\begin{array}{c}\text { (4) } \\
\text { Net } \\
\text { profit } \\
\end{array}$ & $\begin{array}{c}\text { (5) } \\
\text { Tfr to } \\
\text { gen res }\end{array}$ & $\begin{array}{c}(6) \\
\text { Pref } \\
\text { divis } \\
\end{array}$ & $\begin{array}{c}(7) \\
\text { Ord } \\
\text { divis }\end{array}$ & $\begin{array}{c}\begin{array}{c}(8) \\
\text { Bonus } \\
\text { issues }\end{array} \\
\end{array}$ & $\begin{array}{c}\text { (9) } \\
\text { Ret. for } \\
\text { year }\end{array}$ & $\begin{array}{c}(10) \\
\text { Ret pr } \\
\text { b.f. }\end{array}$ & $\begin{array}{c}\text { (11) } \\
\text { Ret pr } \\
\text { c.f. } \\
\end{array}$ \\
\hline 1865 & 7 & 0 & -3 & 4 & & & & & 4 & & 4 \\
\hline 1866 & 188 & -50 & -13 & 125 & & & -54 & & 71 & 4 & 75 \\
\hline 1867 & 159 & -38 & -16 & 106 & & & -64 & -40 & 2 & 75 & 77 \\
\hline 1868 & 138 & -12 & -16 & 110 & & & -68 & -40 & 2 & 77 & 79 \\
\hline 1869 & 167 & -38 & -15 & 114 & & & -72 & -40 & 2 & 79 & 81 \\
\hline 1870 & 151 & -19 & -14 & 118 & & & -76 & -40 & 2 & 81 & 83 \\
\hline 1871 & 231 & -19 & -14 & 199 & & & -115 & -40 & 44 & 83 & 127 \\
\hline 1872 & 304 & -57 & -14 & 234 & & -3 & -155 & & 76 & 127 & 203 \\
\hline 1873 & 431 & -36 & -15 & 380 & & -3 & -170 & -100 & 107 & 203 & 310 \\
\hline 1874 & 156 & 0 & -27 & 129 & & -3 & -154 & -200 & -228 & 310 & 82 \\
\hline 1875 & 99 & 80 & -28 & 152 & & -3 & -171 & & -23 & 82 & 60 \\
\hline 1876 & 102 & 0 & -28 & 75 & & -3 & -61 & & 11 & 60 & 71 \\
\hline 1877 & 144 & 0 & -28 & 117 & & -3 & -131 & & -18 & 71 & 54 \\
\hline 1878 & 135 & 0 & -28 & 108 & & -48 & -78 & & -19 & 54 & 36 \\
\hline 1879 & 108 & -22 & -27 & 59 & & -20 & & & 39 & 36 & 75 \\
\hline 1880 & 88 & -22 & -27 & 39 & & -26 & & & 13 & 75 & 88 \\
\hline 1881 & 254 & -100 & -27 & 127 & & -27 & -113 & & -13 & 88 & 75 \\
\hline 1882 & 166 & -20 & -27 & 119 & & -29 & -120 & & -30 & 75 & 45 \\
\hline 1883 & 67 & 0 & -27 & 40 & & -33 & -45 & & -38 & 45 & 7 \\
\hline 1884 & 82 & -22 & -27 & 33 & & -33 & & & 0 & 7 & 7 \\
\hline 1885 & 45 & -22 & -27 & -4 & & & & & -4 & 7 & 3 \\
\hline 1886 & 36 & -5 & -33 & -2 & & & & & -2 & 3 & 1 \\
\hline 1887 & 52 & -16 & -34 & 2 & & & & & 2 & 1 & 3 \\
\hline 1888 & 94 & -22 & -32 & 40 & & & & & 40 & 3 & 43 \\
\hline 1889 & 134 & -23 & -32 & 79 & & -43 & & & 36 & 43 & 79 \\
\hline 1890 & 161 & -19 & -28 & 114 & & -77 & & & 37 & 79 & 116 \\
\hline 1891 & 133 & -30 & -28 & 75 & -25 & -68 & -28 & & -46 & 116 & 70 \\
\hline 1892 & 75 & -22 & -27 & 26 & -25 & -25 & -28 & & -52 & 70 & 18 \\
\hline 1893 & 29 & -7 & -26 & -4 & 25 & -25 & & & -4 & 18 & 14 \\
\hline 1894 & 0 & -10 & -25 & -35 & 25 & -12 & & & -22 & 14 & -8 \\
\hline 1895 & 27 & -7 & -25 & -5 & & & & & -5 & -8 & -13 \\
\hline 1896 & 113 & -35 & -27 & 51 & & & & & 51 & -13 & 38 \\
\hline 1897 & 85 & -14 & -28 & 43 & -5 & -30 & & & 8 & 38 & 46 \\
\hline 1898 & 94 & -16 & -28 & 50 & -15 & -25 & & & 10 & 46 & 56 \\
\hline 1899 & 118 & -12 & -28 & 78 & -20 & -25 & & & 33 & 56 & 89 \\
\hline 1900 & 247 & -62 & -28 & 157 & & & & & 157 & 89 & 246 \\
\hline 1901 & 119 & -40 & -24 & 55 & & & & & 55 & 246 & 301 \\
\hline 1902 & 110 & -190 & -19 & -99 & & -121 & -27 & & -247 & 301 & 54 \\
\hline Ave & 124 & -24 & -23 & 77 & -1 & -18 & -44 & -13 & 1 & 70 & 72 \\
\hline
\end{tabular}

Sources: as Table 1

Notes: in col (2) Deprec. $=$ Depreciation

in col (3) Debent. = Debentures

in col (5) gen. res. = general reserve

in col (6) Pref. = Preference

in col (7) Ord. = Ordinary

in col (9) Ret. = Retained

in col (10) Ret pr b.f. = Retained profits brought forward

in col (11) Ret pr c.f. = Retained profits carried forward 
Table 3: Barrow Haematite financial ratios, 1865-1902 (\%)

\begin{tabular}{|c|c|c|c|c|c|c|c|}
\hline & $\begin{array}{c}\text { (1) } \\
\text { RoCE } \\
\text { PBIT/CE }\end{array}$ & $\begin{array}{c}\text { (2) } \\
\text { RoE } \\
\text { NP/Eq }\end{array}$ & $\begin{array}{c}\text { (3) } \\
\text { RoOrd } \\
\text { Div/Ord }\end{array}$ & $\begin{array}{c}\text { (4) } \\
\text { RoPref } \\
\text { Div/Pref }\end{array}$ & $\begin{array}{c}\text { (5) } \\
\text { RoDeb } \\
\text { Int/Deb }\end{array}$ & $\begin{array}{c}\text { (6) } \\
\text { Pref\&Deb } \\
\text { to Cap Empt }\end{array}$ & $\begin{array}{c}(7) \\
\text { Deprec } \\
\text { to fix ass }\end{array}$ \\
\hline 1865 & 4.8 & 4.7 & & & -5.0 & 35.2 & \\
\hline 1866 & 16.6 & 21.8 & 10.8 & & -5.0 & 30.7 & 7.3 \\
\hline 1867 & 13.1 & 17.1 & 11.9 & & -5.0 & 33.4 & 4.9 \\
\hline 1868 & 13.0 & 16.8 & 11.7 & & -5.0 & 32.1 & 1.5 \\
\hline 1869 & 12.8 & 16.2 & 11.6 & & -5.0 & 30.4 & 4.7 \\
\hline 1870 & 12.8 & 15.8 & 11.5 & & -5.0 & 27.9 & 2.2 \\
\hline 1871 & 19.3 & 24.0 & 16.4 & & -5.0 & 24.6 & 2.2 \\
\hline 1872 & 20.4 & 25.5 & 22.1 & -7.9 & -5.0 & 25.4 & 6.5 \\
\hline 1873 & 27.3 & 34.0 & 21.3 & -7.9 & -5.0 & 23.3 & 3.3 \\
\hline 1874 & 7.9 & 9.0 & 11.8 & -7.9 & -5.0 & 29.4 & 0.0 \\
\hline 1875 & 8.8 & 10.2 & 12.3 & -7.9 & -5.0 & 28.9 & -5.1 \\
\hline 1876 & 4.3 & 4.7 & 4.2 & -1.1 & -5.0 & 35.2 & \\
\hline 1877 & 6.1 & 7.4 & 8.8 & -1.0 & -5.0 & 35.2 & \\
\hline 1878 & 5.7 & 3.9 & 5.2 & -16.7 & -5.0 & 35.3 & \\
\hline 1879 & 3.4 & 2.5 & & -4.9 & -5.1 & 37.3 & 1.2 \\
\hline 1880 & 2.6 & 0.8 & & -6.2 & -5.0 & 37.6 & 1.1 \\
\hline 1881 & 6.0 & 6.3 & 7.5 & -6.3 & -4.9 & 38.3 & 5.3 \\
\hline 1882 & 5.5 & 5.8 & 8.0 & -5.4 & -4.9 & 41.3 & 1.0 \\
\hline 1883 & 2.6 & 0.5 & 3.0 & -6.1 & -4.9 & 41.9 & \\
\hline 1884 & 2.3 & 2.0 & & -6.1 & -4.9 & 41.8 & 1.0 \\
\hline 1885 & 0.9 & -0.3 & & & -4.9 & 41.9 & 1.0 \\
\hline 1886 & 1.2 & -0.1 & & & -5.1 & 44.2 & 0.2 \\
\hline 1887 & 1.3 & 0.1 & & & -4.9 & 45.1 & 0.7 \\
\hline 1888 & 3.3 & 3.4 & & & -5.0 & 47.2 & 1.3 \\
\hline 1889 & 5.1 & 3.0 & & -10.7 & -5.8 & 44.2 & 1.3 \\
\hline 1890 & 6.5 & 3.0 & & -19.1 & -5.1 & 43.4 & 1.1 \\
\hline 1891 & 4.7 & 0.6 & 2.5 & -16.9 & -5.1 & 43.9 & 1.7 \\
\hline 1892 & 2.5 & 0.1 & 2.5 & -6.2 & -4.9 & 44.4 & 1.2 \\
\hline 1893 & 1.0 & -2.5 & & -6.2 & -4.7 & 45.0 & 0.4 \\
\hline 1894 & -0.5 & -4.2 & & -3.0 & -4.5 & 46.0 & 0.5 \\
\hline 1895 & 1.0 & -0.4 & & & -4.5 & 46.2 & 0.4 \\
\hline 1896 & 3.7 & 4.4 & & & -4.9 & 45.0 & 1.9 \\
\hline 1897 & 3.3 & 1.1 & & -7.4 & -5.1 & 44.8 & 0.8 \\
\hline 1898 & 3.6 & 2.1 & & -6.2 & -5.1 & 44.2 & 0.9 \\
\hline 1899 & 4.8 & 4.4 & & -6.2 & -5.1 & 43.2 & 0.7 \\
\hline 1900 & 7.9 & 11.5 & & & -5.2 & 40.0 & 3.5 \\
\hline 1901 & 3.5 & 3.9 & & & -5.9 & 35.6 & 2.3 \\
\hline 1902 & -5.8 & -13.6 & 4.0 & -50.0 & -5.1 & 44.3 & 21.1 \\
\hline Ave & 6.2 & 6.2 & 4.8 & -5.6 & -4.9 & 37.3 & 2.0 \\
\hline
\end{tabular}

Sources: as Table 1

Notes:

col (1) $=$ Return on Capital Employed (Profits before interest and tax to Capital Employed col (2) = Return on Equity (Net profit less preference dividends to Equity)

col (3) = Return to Ordinary shareholders (Dividends to Ordinary shareholders)

col (4) = Return on Preference (Dividends to Preference shareholders)

col $(5)=$ Return on Debentures (Interest to Debenture holders)

col (6) = Preference \& Debentures to Capital Employed

col $(7)=$ Depreciation to fixed assets 


\section{Archival sources}

Barrow Records Office, BD HJ 163/3/1, Draft deed of agreement Haematite Steel Co Ltd and Schneider and Hannay, 1864.

| Guildhall Library, London, annual reports filed with Stock Exchange-Annual Reports; Barrow Haematite Steel Co Ltd 1883-1964.

\section{National Archives (NA), BT31/1126c/44942-44944, Company files Barrow Haematite Iron and Steel Co Ltd.}

National Archives of Scotland, Buccleuch papers; GD 224/144/5 Printed papers, mainly annual reports of the Barrow Haematite Steel Co Ltd, 1865-82.

Parliamentary Archives, House of Lords, London, Barrow Haematite Steel Co. Ltd Act 1902; An Act to provide for the settlement of questions which have arisen between the preference shareholders and ordinary shareholders in Barrow Haematite Steel Co Ltd and for other purposes, Local Act 2 Edward VII c.ccxxxvii HL/PO/PB/1/1902/2E7n266 1902.

Public Records Office (PRO), BT31/1126c/44942-44944, Company files Barrow Haematite Iron and Steel Co Ltd.

\section{References}

Abe, E., 1996. The technological strategy of a leading iron and steel firm, Bolckow Vaughan and Co. Ltd: late Victorian industrialists did fail. Business History, 38 (1), 45-76.

Ammonia Soda Company v Chamberlain (1918) 1 Ch. 266

Andews, P. W. S. and Brunner, E., 1951. Capital Development in Steel: a Study of United Steel Cos Ltd. London: Blackwell.

Ardern, D. and Aiken, M., 2005. An accounting history of capital maintenance: legal precedents for managerial autonomy in the UK. Accounting Historians Journal, 32 (1), 23-60

Armour, J., 2000. Share capital and creditor protection: efficient rules for a modern Company Law. Modern Law Review, 63 (3), 355-378.

Bannatyne v Direct Spanish Telegraph Company, (1886) 34 Ch. D. 287.

re Barrow Haematite Steel Company, (1888) L.R. 39 Ch. D. 582.

re Barrow Haematite Steel Company, (1900) 2 Ch. 846.

re Barrow Haematite Steel Company, (1901) 2 Ch. 746.

Birch, A., 1967. The Economic History of the British Iron and Steel Industry, 1784-1879. London: Cass.

Blair, M. M. 2003a. Locking in capital: what corporate law achieved for business organizers in the nineteenth century. UCLA Law Review, 51 (2), 387-455.

Blair, M. M. 2003b. Why markets chose the corporate form: entity status and the separation of asset ownership from control. Georgetown Law and Economics Research Paper 429300.

Bond v Barrow Haematite Steel Company, (1902) 1 Ch. 353

Bryer, R. A., 1998. The laws of accounting in late nineteenth century Britain. Accounting History, 3 (1), 55-94. 
Bryer, R. A., 2000. The history of accounting and the transition to capitalism in England. Part one: theory. Accounting, Organizations and Society, 25 (2), 131-62.

Cannadine, D., 1977. The Landowner as Millionaire: The Finances of the Dukes of Devonshire, c. 1880-1926. Agriculture History Review, 25 (2), 77-97.

Carr, J. C. and Taplin, W., 1962. History of the British Steel Industry. Cambridge. Mass: Harvard University Press.

Chiapello, E., 2007. Accounting and the birth of the notion of capitalism. Critical Perspectives on Accounting, 18 (3), 263-96.

Companies Clauses Consolidation Act 1845, (8 \& 9 Vict c 16)

Companies Act 1867 (30 \& 31 Vict c 131)

Companies Act 1877 (40 \& 41 Vict c 26)

Companies Act 1947 (10 \& 11 Geo 6 c 47)

Companies Act 1948 (11 \& 12 Geo 6 c 38)

Companies Act 1981 (c 31)

Companies Act 1985 (c 6)

Companies Act 2006 (c 46)

Cottrell, P. L., 1980. Industrial Finance 1830-1914. London: Methuen.

re Ebbw Vale Steel, Iron, and Coal Company, (1877) 4 Ch. D. 827.

Edwards, J. R., 1980. British capital accounting practices and business finance 1852-1919: an exemplification. Accounting and Business Research, 10, 241-58.

Edwards, J. R., 1989. A History of Financial Accounting. London: Routledge.

Ferran, E., 1999. Company Law and Corporate Finance. Oxford: Oxford University Press.

Floud, R., 1994. Britain, 1860-1914: a survey, in Floud, R and D. McCloskey (eds.) The Economic History of Britain since 1700, Vol 2: 1860-1939 (second ed.), 1-28.

French, E. A., 1977. The evolution of the dividend law of England, in Baxter, W. T. and Davidson, S. (eds). Studies in Accounting, London: Institute of Chartered Accountants in England and Wales. 306-31.

Hicks, J. R., 1948. Value and Capital (Second edition). Oxford: Oxford University Press.

Hope v International Financial Society Ltd, (1877) 46 L. J. Ch. 200.

Inflation Accounting. 1975. Report of the Inflation Accounting Committee (Sandilands Committee), Cmnd. 6225. London: HMSO.

Jefferys, J. B., 1946. The denomination and character of shares, 1855-1885. Economic History Review, 16 (1), 45-55.

Joint Stock Companies Act 1856 (19 \& 20 Vict c 47).

re Kingston Cotton Mills Co. No. 2 (1896) 1 Ch 331. 
Lee v Neuchatel Asphalte Company, (1889) 41 Ch. D. 1.

Limited Liability Act 1855 (18 \& 19 Vict c 133).

Marshall, A., 1890. Principles of Economics, Vol. 1. London: Macmillan.

Marshall, J. D., 1958. Furness and the Industrial Revolution. Barrow: Barrow-in-Furness Library and Museum Committee.

Marx, K., 1978. Capital (Volumes 1 and 2). Harmondsworth, Middlesex: Penguin.

Mason, P., 1932. Profits and surplus available for dividends. Accounting Review, 7 (1), 61-66.

| Mayson, S. W., French, D. and Ryan, C., 1996. Company Law (Thirteenth edition). London: Blackstone Press.

McCartney, S. and A. J. Arnold, 2012. Financial capitalism, incorporation and the emergence of financial reporting information. Accounting, Auditing and Accountability Journal, 25 (8), 1290-1316.

McCloskey, D. N., 1970. Did Victorian Britain fail? Economic History Review. 23 (3), 446-459.

Morris, R. D., 1986. Lee v. Neuchatel Asphalte Company (1889) and depreciation accounting: two empirical studies. Accounting and Business Research, 16, 71-81.

Napier, C. J., 2015. The British aristocracy, capital and income. Paper presented at the Eighth Accounting History International Conference, Ballarat, Australia.

Pickering, M. A., 1963. The problem of the preference share. Modern Law Review, 26 (5), 499519.

Pollard, S., 1954. Town planning in the nineteenth century: the beginnings of modern Barrowin-Furness. Transactions of the Lancashire and Cheshire Antiquarian Society, 87-116.

Pollard, S., 1955. Barrow-in-Furness and the Seventh Duke of Devonshire. Economic History Review, VIII (2), 213-21.

Pollard, S. and Marshall, J. D., 1953. Furness Railway and the growth of Barrow. Journal of Transport History, 1 (2), 109-26.

Reid, J. M., 1986. Law and Accounting: pre-1889 British Legal cases. New York: Garland.

Reid, J. M., 1987a. Judicial intervention in accounting behavior: a reevaluation of the nineteenth century experience. Journal of Accounting and Public Policy, 6, 9-34.

Reid, J. M., 1987b. Judicial views on accounting in Britain. Accounting and Business Research, 17, 247-58.

Reid, J. M., 1988. Legal acceptance of accounting principles in Great Britain and the United States. Accounting Historians Journal, 15 (1), 1-27.

Ribstein, L. E., 2005. Should history lock in lock-in? Tulsa Law Review, 41, 523-40.

Roepke, H. G., 1956. Movements of the British Iron and Steel Industry, 1720 to 1951. Urbana: University of Illinois Press. 
Rutterford, J., J. Maltby, D. R Green and A. Owens, 2009. Researching shareholding and investment in England and Wales: Approaches, sources and methods. Accounting History 14 (3) $269-292$

Toms, J. S., 2010. Calculating profit: a historical perspective on the development of capitalism. Accounting, Organizations and Society, 35 (2), 205-21.

Trevor v Whitworth (1887), 12 App Cas 409, HL.

Verner v General and Commercial Investment Trust (1894) 2 Ch 239.

Yamey, B. S., 1941. Aspects of the law relating to company dividends. Modern Law Review, 4 (4), 273-98.
Formatted: Font: Bookman Old Style, 10 pt Formatted: Font: Bookman Old Style, $10 \mathrm{pt}$ Formatted: Font: Bookman Old Style, $10 \mathrm{pt}$, Not Italic

Formatted: Font: Bookman Old Style, 10 pt

Formatted: Font: Bookman Old Style, 10 pt 